\title{
Mitochondrial metabolism as a target for acute myeloid leukemia treatment
}

\author{
Svetlana B. Panina, Jingqi Pei and Natalia V. Kirienko* (1)
}

\begin{abstract}
Acute myeloid leukemias (AML) are a group of aggressive hematologic malignancies resulting from acquired genetic mutations in hematopoietic stem cells that affect patients of all ages. Despite decades of research, standard chemotherapy still remains ineffective for some AML subtypes and is often inappropriate for older patients or those with comorbidities. Recently, a number of studies have identified unique mitochondrial alterations that lead to metabolic vulnerabilities in AML cells that may present viable treatment targets. These include mtDNA, dependency on oxidative phosphorylation, mitochondrial metabolism, and pro-survival signaling, as well as reactive oxygen species generation and mitochondrial dynamics. Moreover, some mitochondria-targeting chemotherapeutics and their combinations with other compounds have been FDA-approved for AML treatment. Here, we review recent studies that illuminate the effects of drugs and synergistic drug combinations that target diverse biomolecules and metabolic pathways related to mitochondria and their promise in experimental studies, clinical trials, and existing chemotherapeutic regimens.
\end{abstract}

Keywords: Acute myeloid leukemia (AML), Mitochondria, Mitochondrial abnormalities/alterations, Mitochondrial metabolism, Mitocans, Leukemia stem cells, Synergy, Drug combinations

\section{Background}

Acute myeloid leukemias (AML) are a group of hematological cancers that involve clonal proliferation of immature myeloid progenitor cells in the bone marrow and peripheral blood. These myeloblasts tend to be intensely proliferative, even to the extent that they can compromise normal blood flow. Proliferation of the myeloblasts generates a bulk of largely non-functional cells, compromising hematopoiesis, leading to neutropenia and increasing vulnerability to infectious disease. AML is one of the most common leukemias to affect adults ( 120,000 new cases per year worldwide) and is also one of the most lethal. Left untreated, most forms of AML are aggressive and patients can succumb to disease in weeks to a few months [1].

The most common chemotherapy treatment for AML is called induction and consolidation. The first stage,

\footnotetext{
* Correspondence: kirienko@rice.edu

Department of BioSciences, Rice University, Houston, TX, USA remission induction, is intended to reduce the bulk of the myeloblasts. Induction involves high doses of cytarabine, a nucleoside analog that compromises DNA replication, with an anthracycline antibiotic such as daunorubicin. The induction phase usually lasts for 7 days. After remission has been triggered, treatment moves into the consolidation stage. This step typically involves several 3-day courses of cytarabine, but can also involve hematopoietic stem cell transplantation [2]. Although the precise anti-cancer mechanism of the combination of cytarabine and anthracyclines is still poorly understood, they are believed to function by inflicting DNA damage, which leads to mitochondrial dysfunction and apoptosis [3]. The length of these courses has led to this treatment often being referred to as " $7+3$ " induction and consolidation.

Although induction and consolidation is one of the most effective treatments currently available for AML, it is very hard on patients. This renders the treatment

(c) The Author(s). 2021 Open Access This article is licensed under a Creative Commons Attribution 4.0 International License, which permits use, sharing, adaptation, distribution and reproduction in any medium or format, as long as you give appropriate credit to the original author(s) and the source, provide a link to the Creative Commons licence, and indicate if changes were made. The images or other third party material in this article are included in the article's Creative Commons licence, unless indicated otherwise in a credit line to the material. If material is not included in the article's Creative Commons licence and your intended use is not permitted by statutory regulation or exceeds the permitted use, you will need to obtain permission directly from the copyright holder. To view a copy of this licence, visit http://creativecommons.org/licenses/by/4.0/ The Creative Commons Public Domain Dedication waiver (http://creativecommons.org/publicdomain/zero/1.0/) applies to the data made available in this article, unless otherwise stated in a credit line to the data. 
inappropriate for many older patients (65 years or older, who comprise more than half of all newly diagnosed patients), especially those with other contra-indicators, like secondary disease, adverse genotypes, or treatmentresistant cancers [4]. Although there are several options for these patients, including low-dose induction therapy or more targeted treatments, which will be discussed below, most of these treatments are associated with a reduced likelihood of remission (and shorter survival) compared with aggressive chemotherapy. For a large number of patients, only palliative care is available [4]. Problematically, the risk of relapse is high in AML; about one-third of patients who receive even intensive chemotherapy suffer relapse [4].

Despite limited treatment options, virtually no new treatments were approved for AML in the period between 1971 and 2017 [5]. New treatments have been released since, such as a liposomal combination of cytarabine and daunorubicin known as CPX-351, the isocitrate dehydrogenase inhibitor ivosidenib, the tyrosine kinase inhibitor gilteritinib, the sonic hedgehog inhibitor glasdegib, or the $\mathrm{Bcl}-2$ inhibitor venetoclax [6, 7]. Many of these newer treatments target metabolic differences in tumor cells that will be discussed below.

In this review, we discuss studies that explore mitochondrial characteristics of AML myeloblasts and stem cells, in comparison with their normal counterparts, including alterations in metabolism and signaling, mitochondrial respiration, ROS generation and sensitivity, mitochondrial "priming", and mitophagy. Also, we describe various groups of mitocans-mitochondria-targeting chemotherapeutics-and their effects with regard to biology of AML cells. Finally, this review provides recent evidence on synergistic drug combinations based on mitocans targeting diverse metabolic pathways that have shown promising results by in vitro, in vivo studies, and clinical trials in AML patients.

\section{Metabolic differences in LSCs}

If curing AML was as simple as clearing the rapidly dividing, highly proliferative myeloblasts, treatment would be onerous, but straightforward. Unfortunately, it is not so simple as this. Most patients have a second population of leukemic cells known as leukemic stem cells (LSCs). LSCs share many characteristics with normal hematopoietic stem cells (HSCs), including being CD $38^{+}$ CD34, $4^{-}$although LSCs often express other membrane markers that are absent from HSCs (however, the expression of these markers seems to vary among patients) [8]. Like HSCs (and unlike AML myeloblasts), LSCs divide slowly, making conventional anti-proliferative treatments less effective on them. LSCs also provide a reservoir for the re-emergence of the rapidly dividing myeloblasts and are the most common driving force for relapse and treatment resistance, which occurs in about half of all patients who can be treated with aggressive chemotherapy regimens and more than $80 \%$ of patients who cannot. Transfer of LSCs to a naïve host can recapitulate the onset of AML [9-12].

Many studies have reported a unique metabolic signature in AML cells [13]. Metabolic reprogramming in leukemic cells transcends the conventional Warburg effect [14], and includes increased glycolysis and elevated ROS levels possibly regulated by PI3K/AKT and mTOR pathways $[15,16]$. Correspondingly, a higher level of anabolic pathway precursors, such as intermediates of the citric acid cycle (CAC) and the pentose phosphate pathway (PPP), have been found in AML [14]. High biosynthetic pathway activity is required for the production of the materials essential for cell growth and proliferation. Glutaminolysis is upregulated, and catabolism of this amino acid is a valuable source of both carbon and nitrogen [14]. Glutaminolysis also regulates OxPhos (oxidative phosphorylation) in AML through the production of NADH [14]. However, dysregulation of antioxidants has been found in AML, which potentially promotes leukemogenesis by increasing ROS level [1719]. Altered lipid metabolism promotes the interaction of AML with bystanding cells, such as adipocytes, activates their lipolysis, and transfers lipids from adipocytes to myeloblasts [20]. Leukemic cells also tend to upregulate fatty acid oxidation via mitochondrial uncoupling [21]. Mutations in cytosolic and mitochondrial isocitrate dehydrogenases (IDH1 and IDH2), resulting in the production of the oncometabolite 2-hydroxyglutarate, are commonly seen in AML cells, and are frequently targeted for therapy, since they limit cellular differentiation and promote leukemogenesis $[22,23]$.

Part of the difficulty in treating AML is the profound metabolic differences in LSCs [24]. To a first approximation, LSCs retain much of the metabolic profile of healthy HSCs. In addition to dividing more slowly (making them more resistant to nucleoside analogs that disrupt DNA replication), LSCs rely upon oxidative phosphorylation (OxPhos) for ATP generation instead of glycolysis and lactic acid fermentation (the route most tumors use to obtain ATP). This does leave them vulnerable to the production of ROS, which can force cells out of quiescence and trigger programmed cell death pathways. Most ROS are generated in mitochondria via electron transport. LSCs respond to this threat by upregulating autophagy (which is critical for the maintenance of stemness and the elimination of damaged mitochondria that will produce excess ROS) and upregulate the expression of the hypoxic response transcription factor HIF- $1 \alpha$, even in normoxia, to further limit ROS production $[25,26]$. Interestingly, LSCs tend to be metabolically 
inflexible and rely heavily on fatty acid oxidation and glutaminolysis to maintain OxPhos [27, 28].

\section{Glycolytic disruptions in AML blasts and LSCs}

As noted above, myeloblasts have high glycolytic activity and its anabolic diversions, most importantly the pentose-phosphate pathway, to provide nucleotides, amino acids, and electron carriers, e.g., building blocks that are necessary for rapid proliferation of leukemia cells [29]. The first step of glycolysis, the conversion of glucose to glucose-6-phosphate, is catalyzed by hexokinases. Hexokinase II, the most common version of the enzyme in insulin-sensitive tissues, is a key player in controlling metabolic flux through this pathway. Unsurprisingly, it is also frequently upregulated in cancer cells (reviewed in [30,31]). One potential method to target hexokinase is to use 3-bromopyruvic acid or 2-deoxy-Dglucose (2-DG), both of which inhibit glucose metabolism [32, 33]. Although targeting hexokinase with 2-DG alone is generally ineffective, it can sensitize AML cells to other drugs that affect mitochondria, including cytarabine, inhibitors of complex I of the ETC (such as rotenone), the mitochondrial uncoupler $\mathrm{CCCP}$, and $\mathrm{BH} 3-$ mimetic inhibitors of Bcl-2, like ABT-737 [13, 34, 35] (see Figs. 1 and 2 for an overview of druggable mitochondrial targets).

The next rate-limiting, and first committed, step in glycolysis is phosphorylation of 6-phosphofructose by phosphofructokinase-1 (PFK1) to produce fructose 1,6bisphosphate. PFK1 is allosterically activated by the compound fructose 2,6-bisphosphate, which is overproduced in many cancer types by the overexpression of PFKFB3, a dual function 6-phosphofructo-2-kinase/fructose-2, 6-bisphosphatase that is a therapeutic target itself [36]. Overexpression of PFKFB3, including in leukemia cells, drives increased activity of PFK1, enabling increased glycolytic flux. Computational analysis demonstrated that a novel tumor suppressor, 3-(3-pyridinyl)-1(4-pyridinyl)-2-propen-1-one (3PO), can competitively inhibit PFKFB3, and decreases intracellular concentrations of fructose 2,6-bisphosphate; this subsequently decreases glycolytic flux in various tumor models [37]. The same group synthesized 73 derivatives of 3PO, one of which (PFK15) was pre-clinically evaluated for targeting resistant hypoxic cancer cells [37]. 3PO was shown to effectively reduce lactate production and cell growth in a leukemia model [38].

A careful analysis of AML patients has revealed a variety of different genetic contributions to disease progression, including some that alter glycolytic activity. One commonly mutated gene is the FMS-like tyrosine kinase 3 gene (known as CD135 or FLT3). Although several amino acid substitutions have been found, the most common category of mutation identified is internal tandem duplication of one or more codons near the transmembrane domain (known as FLT3-ITD). This class of mutations is found in approximately one-third of AML patients and is associated with poor prognosis and increased risk of relapse [39-42]. Oncogenic mutations in FLT3 trigger overactivation of the tyrosine kinase, which promotes several pro-survival effects in cells, including AKT-mediated upregulation of hexokinaseincreasing their glycolytic activity [43]. There has been an explosion in treatments available for patients with FLT3 mutations, including a number of tyrosine kinase inhibitors like midostaurin and lestaurtinib (derivatives of staurosporine that target multiple tyrosine kinases), sorafenib, quizartinib, crenolanib, and gilteritinib [44]. Of these, only midostaurin and gilteritinib have received approval from the US Federal Drug Agency, and the latter is the first drug identified to target both internal tandem duplications and tyrosine kinase domain mutations [45]. The metabolic shift caused by the mutation also sensitizes these cells to glycolytic inhibitors like 3bromopyruvate, which potentiates treatment with tyrosine kinase inhibitors [34, 43].

\section{Citric acid cycle disruptions in AML blasts and LSCs}

Targeting enzymes involved in the flux of pyruvate into the mitochondrial metabolism or citric acid cycle (CAC) is another fruitful anti-leukemia strategy. In the transition between glycolysis and the CAC cycle, pyruvate needs to be decarboxylated and condensed with coenzyme A (CoA) to yield acetyl-CoA that can be combined with oxaloacetate to yield citrate. Acetyl-CoA production requires the pyruvate dehydrogenase complex (PDC), which is comprised of three different enzymes [46]. Interestingly, cancer tissues often exhibit increased expression of PDC kinases, which limit CAC activity, driving pyruvate toward conversion to lactate, with important implications for energy production and modification of the tumor microenvironment. High expression of PDKs in AML patients (particularly PDK3, which is the most active isoform) is a negative prognostic factor for survival [47].

Several synthetic inhibitors of PDKs have been identified, such as Nov3r, AZD7545, Pfz3, radicicol, and CPI613 [46]. The addition of CPI-613 to conventional chemotherapy is a promising approach for older AML patients and those with poor-risk cytogenetics [48]. Unfortunately, most of these compounds have $\mathrm{IC}_{50}$ values in the low- to mid-millimolar range, suggesting that it would be very difficult to deliver appropriate concentrations of these compounds to tumor cells, particularly without unacceptable levels of off-target effects.

Mutations in the isocitrate dehydrogenase $(I D H)$ genes of AML patients provided researchers with one of their 


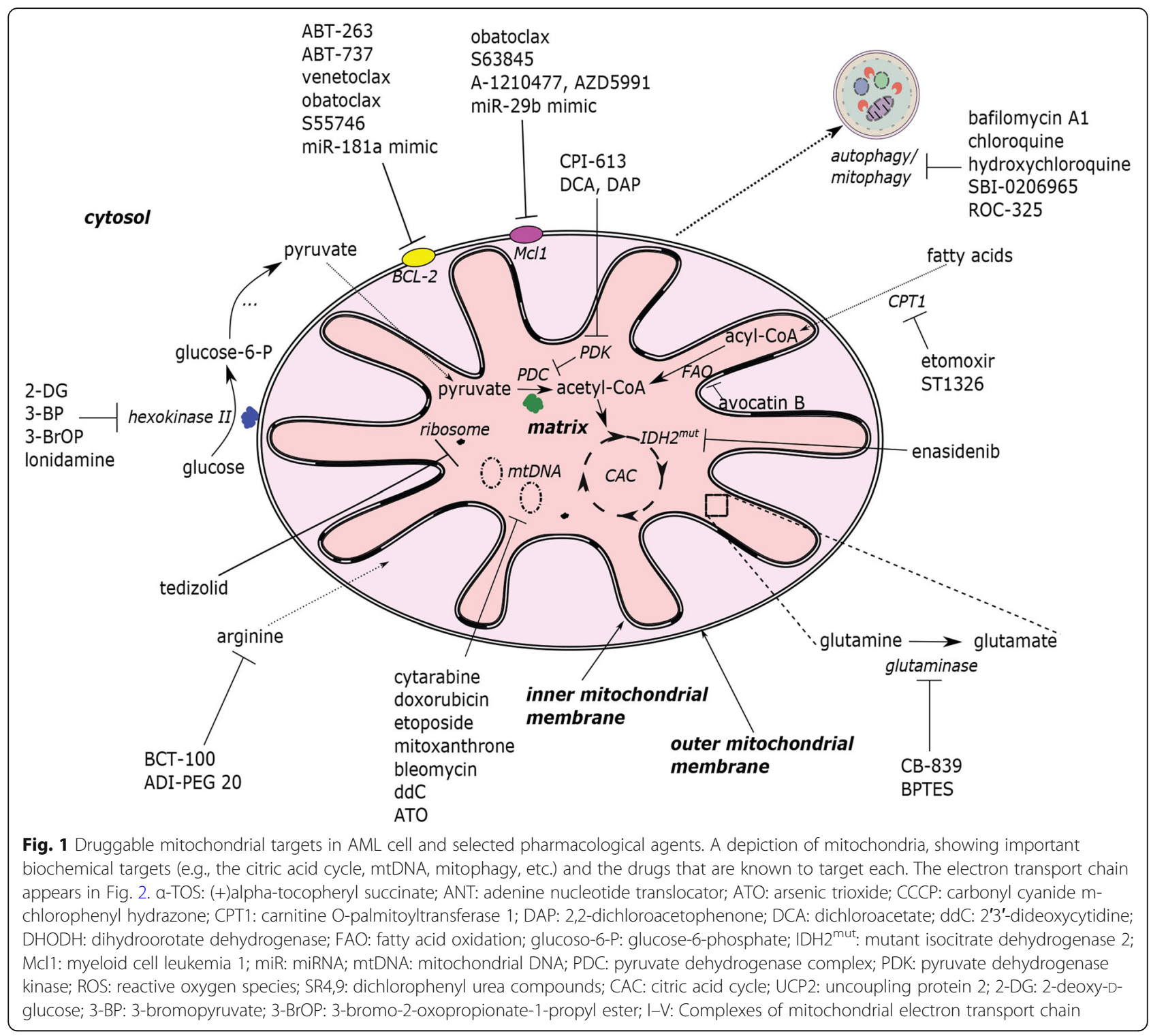

first hints that mitochondrial metabolism was compromised in AML [30]. This occurs in 20\% of AML cases and is associated with grim prognoses (median survival after diagnosis is approximately 6 months) [49]. Commonly, this results in neofunctionalization of IDH1 (cytoplasmic) and IDH2 (mitochondrial) enzymes, allowing them to convert $\alpha$-ketoglutarate into 2-hydroxyglutarate. This onco-metabolite interferes with cellular metabolism and epigenetic regulation [50] and contributes to mitochondrial DNA instability [51]. It is believed that the ability of 2-hydroxyglutarate to interfere with processes that require $\alpha$-ketoglutarate, such as histone and DNA demethylation, is also likely to interfere with the prolyl hydroxylases that regulate HIF-1 $\alpha$ [52]. As noted above, HIF- $1 \alpha$ is well known to play important roles in HSC and LSC maintenance [53]. Recently, ivosidenib and enasidenib, inhibitors of IDH1 and IDH2, have been approved by the US FDA for AML treatment [54]. Mutant IDH proteins can induce a reversible block of differentiation in leukemic cells by preventing IDH enzyme function [55].

\section{Glutamine: key amino acid for cancer cell viability}

Although cancer cells require a wide variety of materials for their survival and growth, at the most basic level this can be reduced to the demand for two nutrients: glucose (for anaerobic glycolysis) and glutamine [56]. Glutamine's uniquely important role in cancer arises from its ability to activate the key mTORC1 pathway (which integrates myriad inputs to regulate metabolic activity, autophagy, and apoptosis) [57, 58]. Glutamine can also be condensed with cysteine and glycine to form glutathione, which supports redox 


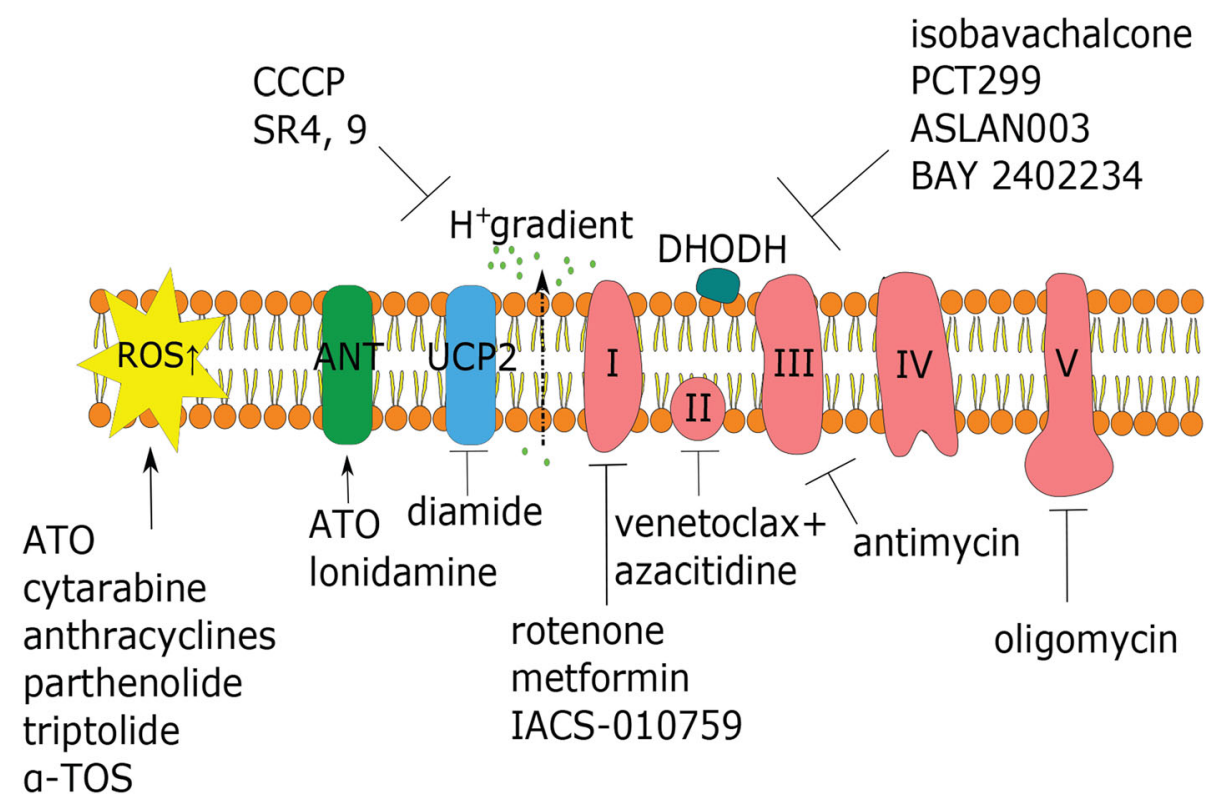

Fig. 2 Mitochondrial electron transport chain (ETC) as a therapeutic target in AML. A schematic representation of the ETC, showing the five complexes and potential therapeutic compounds that target each. Also shown is ROS, since the ETC is a major producer of the ROS in the cell by way of electron leak through complexes I and III. ATO: arsenic trioxide; a-TOS: (+)alpha-tocopheryl succinate; ANT: adenine nucleotide translocator; CCCP: carbonyl cyanide m-chlorophenyl hydrazone; DHODH: dihydroorotate dehydrogenase; ROS: reactive oxygen species; SR4,9: dichlorophenyl urea compounds; UCP2: uncoupling protein 2; I-V: complexes of mitochondrial electron transport chain

regulation and limits ROS damage; it also provides nitrogen for the synthesis of nucleotides for DNA replication $[29,59]$.

The key first step in the use of glutamine is carried out by glutaminase, which deaminates glutamine to yield glutamate. Inhibiting glutaminases has proven to be a popular anti-cancer strategy [60]. The most effective current candidate is Calithera's telaglenastat, also known as CB-839. As might be expected, given the functions of glutamine in cancer, telaglenastat increases susceptibility to redox-targeting therapies like arsenic trioxide and homoharrintonine and improves rates of AML apoptosis [61], while decreasing mTOR signaling [60].

Several AML mutations are known to generate idiosyncratic sensitivities to glutamine metabolism. For example, BPTES, from which CB-839 was derived, exhibits some specificity for $I D H$-mutated AML cells [62]. FLT3ITD mutations are another example: aberrant FLT3 expression likely increases glutaminolysis. Inhibiting function with the tyrosine kinase inhibitor AC220 (also known as quizartinib) impairs glutamine uptake and glutathione production, hypersensitizing AML cells to oxidative stress [63]. Combination treatment of FLT3ITD AML cells/primary samples with CB-839 and AC220 consistently resulted in reduced oxygen consumption, increased ROS production, and the activation of apoptosis [64].

\section{Dependency on mitochondrial mass, mitochondrial respiration, and OxPhos}

Both myeloblasts and LSCs have been shown to have increased mitochondrial mass compared with their healthy counterparts, although this difference is more pronounced in myeloblasts than in the $\mathrm{CD} 34^{+} \mathrm{CD} 38^{-} \mathrm{LSCs}$, further demonstrating the metabolic differences between these populations [65]. Intriguingly, this increase is not associated with a concomitant increase in respiratory function; instead, these cells exhibit a reduced spare reserve capacity, suggesting that their mitochondria are much less efficient [66]. Moreover, we have recently shown that AML cells have reduced coupling efficiency with underlying pre-existing proton leak and enhanced sensitivity to mitochondrial uncouplers compared with normal blood cells [67]. Interestingly, these phenotypes have led to the suggestion that AML progression requires increased mitochondrial biogenesis and OxPhos [67-71].

The importance of OxPhos is further highlighted by the fact that a cytarabine-resistant population of AML cells show enrichment not in LSCs per se, but in cells with up-regulated mitochondrial mass, membrane potential, and OxPhos. Importantly, inhibiting the latter improved sensitivity to cytarabine [68]. Quiescent LSCs with a low level of ROS are more reliant on oxidative phosphorylation, as they cannot efficiently utilize 
glycolysis for energy homeostasis [72]. Consistent with this, the antimicrobial tigecycline, which inhibits mitochondrial translation, selectively kills LSCs (compared with HSCs) by compromising mitochondrial biogenesis in AML cells [65]. Unfortunately, a clinical trial studying the efficacy of intravenous infusion of tigecycline for refractory AML patients failed to show a clinical response, possibly due to the drug's short half-life [73]. Intriguingly, AML cells, including LSCs, are capable of taking up functional mitochondria from other cells in their environment, such as bone marrow cells, increasing their mitochondrial mass, and this phenomenon is thought to contribute to chemoresistance $[74,75]$. This mitochondrial transfer increases during chemotherapeutic treatment and was proposed as an additional mechanism that provides AML cells with energy [75]. More specifically, bone marrow mesenchymal stem cells significantly protect leukemic cells from chemotherapy-induced ROS by increasing glutathione availability and utilization, mainly via the glutathione peroxidase system [75].

Mutations in mitochondrial genes that encode complexes I, III, and IV of the electron transport chain (ETC) have been linked to worsened outcomes in AML patients, suggesting that loss of proper function exacerbates disease [76]. However, there is substantial evidence that the complexes of the ETC are viable targets for therapeutic intervention, including in AML. For this reason, various strategies to disable mitochondrial ETC have been investigated in AML.

Among complex I inhibitors, the best known are the anti-diabetic biguanide metformin and the compound IACS-010759 (reviewed in [77, 78]). Metformin stimulates metabolic reprogramming, increasing glycolysis, pentose phosphate pathway, and fatty acid and anaplerotic metabolism and changing mitochondrial gene expression in leukemic cells [79]. Unfortunately, metformin is ineffective as an anti-AML agent on its own. Although it blocks mitochondrial respiration, it barely affects target cell proliferation or viability [77, 80].

In contrast, a more potent complex I inhibitor, IACS010759, robustly inhibits proliferation and induces apoptosis, likely through a combination of energy depletion and impaired nucleotide biosynthesis due to reduced glutaminolysis [81]. Clinical trials with IACS010759 for AML patients are still ongoing [81], but there have already been reports of it being used in combination with venetoclax, which showed strong promise at targeting LSCs and myeloblasts using a PDX model [82]. Similarly, we have recently determined that IACS010759 can synergize with vinorelbine to improve efficacy and specificity, including in primary cells from AML patients [35].

In that same study, we also determined that rotenone, a well-known inhibitor of complex I, could synergize with the glycolytic inhibitor 2-DG. Rotenone has previously been investigated as a potential cancer therapeutic [83], although it was determined that its off-target toxicity and resultant hematopoietic suppression make it inappropriate for use at the dosages required to prevent proliferation [84]. By pairing it with other compounds, the dose required for efficacy can be significantly reduced, increasing the chance that the targeted effects would be more specific [35].

More recently, another drug called mubritinib (also known as TAK-165) was shown to have a strong effect in vivo against AML [85]. Mubritinib, canonically an inhibitor of ERBB2 (a receptor tyrosine kinase of the EGF receptor superfamily), was shown to inhibit the transfer of electrons through the ETC by blocking the function of complex I at ubiquinone [85]. This mechanism is similar to rotenoids and has similar efficacy.

Most attempts to target the ETC have focused on complex I, but some limited research has been performed on other ETC complexes. For example, a combination of venetoclax and azacytidine appears to have a synergistic effect that blocks glutathionylation of succinate dehydrogenase A (a component of complex II) and kills both myeloblasts and LSCs [86]. Targeting complex III may also be productive. For example, antimycin A more effectively limits oxidative phosphorylation and generates increased ROS production in primary AML cells [66]. As will be discussed in the next section, AML cells and LSCs are more sensitive to ROS than their healthy counterparts. Like rotenone, antimycin A is a well-known inhibitor of mitochondrial function; also like rotenone, it is unlikely to be successfully utilized on its own as a therapeutic due to off-target activity. However, it has been effectively combined with a third-generation glycolytic inhibitor, 3-bromo-2-oxopropionoate-1-propyl ester, which serves as a cell-permeable ester of 3bromopyruvate [87]. This combination potentiated ATP depletion and promoted apoptosis in leukemic cells [87]. It has also shown potential in combination with rapamycin in leukemia and neuroblastoma [87, 88]. Finally, targeting the mitochondrial ATP-synthase (sometimes called complex V) with oligomycin A greatly sensitized leukemia cells to tyrosine kinase inhibitors in FLT3dependent AML cells, both in vitro and in vivo [89].

Disruption of the ETC on a wider scale is also effective at reducing leukemia cell viability. By targeting the mitochondrial protease $\mathrm{ClpP}$ with a beta-lactone inhibitor called A2-32-01, Cole and colleagues demonstrated that this compound was effective at killing leukemia cells with high levels of ClpP expression [90]. Interestingly, this phenotype only appears in approximately half of the leukemic cell lines that were analyzed. Multiple publications have demonstrated that many of the targets of the ClpP protease are members of the ETC complexes [90, 
91], perhaps to ensure that the components of the complexes remain in stoichiometric balance.

\section{Modulation of mitochondrial ROS as AML treatment strategy}

The formation of ROS is essential for normal cell physiology (Fig. 3); ROS are generated during mitochondrial oxidative metabolism as well as in response to exposure to xenobiotics, cytokines, and bacterial invaders [92]. But ROS have also long been acknowledged as having a role in cellular signaling [93, 94]. For instance, mitochondrial ROS stimulate signaling pathways promoting tumorigenesis such as JNK/ERK, HIF-1 $\alpha$, and mitochondrial biogenesis [94]. ROS have also been shown to regulate protein function (including kinases and phosphatases) via various oxidative post-translational modifications [93].

Superoxide anions $\left(\mathrm{O}_{2}{ }^{-}\right)$are produced as side products from the respiratory chain in mitochondria, by NADH oxidases $1-3$ and 5 (NOX), and by other cellular enzymes. The electron transport chain, predominantly complexes I and III, is a major source of superoxide. During oxidative phosphorylation, $1-5 \%$ of electrons escape from ETC and produce $\mathrm{O}_{2}{ }^{-}$[93]. All NOX family members are transmembrane proteins that use intracellular NADPH to reduce extracellular oxygen to ROS [93]. Interestingly, NOX-derived ROS are linked to activating mutations in FLT3 and Ras: FLT3-ITD mutation in AML causes Akt activation and subsequent stabilization of $\mathrm{p} 22^{\text {phox }}$, a regulatory subunit for NOX1-4 [93, 95]. Moreover, in human AML, NOX2-derived superoxide stimulates bone marrow stromal cells to transfer their mitochondria to AML blasts [96]. Superoxide anions are converted to hydrogen peroxide $\left(\mathrm{H}_{2} \mathrm{O}_{2}\right)$ by various superoxide dismutases, which are found in several subcellular compartments (the charged nature of superoxide limits its ability to move throughout the cell). Hydrogen peroxide is also produced by NOX4. Other reactive species, such as the short-lived hydroxyl radical $(\mathrm{OH})$, lipid hydroperoxides, peroxynitrite $\left(\mathrm{NO}_{3}{ }^{-}\right)$, and hypochlorous acid $(\mathrm{HClO})$, arise by metabolic reactions involving superoxide or $\mathrm{H}_{2} \mathrm{O}_{2}$ [95].

For normal HSCs, ROS present a significant threat, as they can trigger apoptosis, loss of quiescence, or induce differentiation [97]. As noted above, this is also true of LSCs. Metabolic adaptations to limit this sensitivity are likely to emerge and may include increased proton leak down the electrochemical gradient into the mitochondrial matrix [98], mitochondrial uncoupling (abrogation of ATP synthesis in response to $\Delta_{\Psi_{\mathrm{m}}}$ ) [99], and

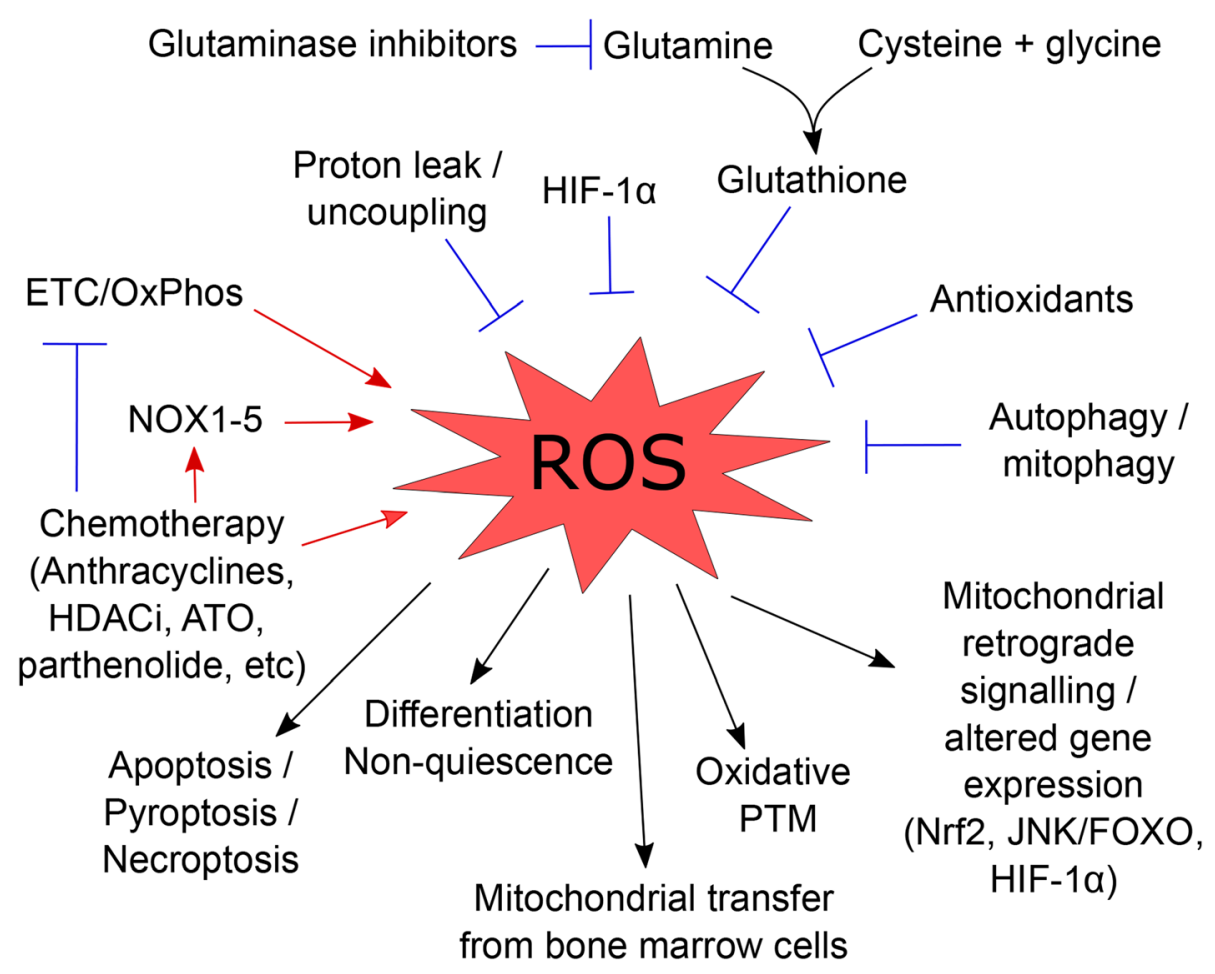

Fig. 3 Central role of reactive oxygen species (ROS) in AML biology and treatment. A representation of the wide variety of factors that produce and limit the production of ROS in AML, along with the outcomes of excess ROS production in these cells. ETC: electron transport chain; FOXO: forkhead box protein O; HDACi: histone deacetylases inhibitors; HIF-1a: hypoxia-inducible factor 1a; JNK: c-Jun N-terminal kinase; Nrf2: nuclear factor erythroid 2-related factor 2; NOX: NADH-oxidases; OxPhos: oxidative phosphorylation; PTM: post-translational modifications 
increased autophagy. These events also promote the Warburg effect and cataplerotic reactions from the CAC and support the shift toward glutaminolysis-dependent fatty acid oxidation (FAO) [100]. This may be why disrupting these events is effective at killing cancer cells. The reduced spare respiratory capacity of AML myeloblasts also makes them unusually vulnerable to oxidative metabolic stress, indicating that increasing ROS may be a viable clinical strategy [66].

The potential for killing AML cells using ROS has been reviewed recently [93]. Redox-based treatments of hematological malignancies can be divided into two different approaches: 1) compounds that stimulate the overproduction of ROS; and 2) compounds that compromise the mitochondrial antioxidant system [101]. It is known that many AML treatments and novel compounds with anti-leukemic activities stimulate ROS production, including cytarabine and anthracyclines (the well-known components of induction and consolidation therapy), histone deacetylase inhibitors, such as vorinostat, and the proteasome inhibitor bortezomib [101, 102]. For example, the cytotoxic effects of the anthracycline doxorubicin are linked to the stimulation of the Fenton reaction that generates lethal hydroxyl radicals from superoxide [103]. The Fenton reaction requires the presence of heavy metals such as iron. One side effect of doxorubicin treatment is the preferential accumulation of iron inside of mitochondria [104]. Contrary to anthracyclines, the HDAC inhibitor vorinostat up-regulates ROS generation in leukemic cells by activating NADH oxidases [105]. Furthermore, the combination of vorinostat and PEITC ( $\beta$-phenylethyl isothiocyanate), depleting antioxidant glutathione, acts synergistically in AML cells via modulating cellular redox status and $\mathrm{H}_{2} \mathrm{O}_{2}$ accumulation [105].

Arsenic trioxide (ATO) is another interesting example. ATO is a potent ROS inducer and is widely used in combination with all-trans retinoic acid (ATRA) to treat acute promyelocytic leukemia (APL), a subtype of AML $[106,107]$. ATRA functions in this combination to stimulate differentiation of promyelocytic blast cells, which then spontaneously undergo apoptosis. ATRA also appears to trigger mitochondrial permeability transition and cell death [31]. ATO has replaced anthracycline antibiotics (e.g., daunorubicin, doxorubicin, etc.) as the choice companion drug to treat APL since it exhibits less severe side effects [108]. The cytotoxic effects of ATO on leukemic cells include oxidative stress induction, depolarization of the mitochondrial membrane, DNA damage, and induction of apoptosis [109]. More specifically, ATO increases superoxide generation in leukemia cells by inhibiting mitochondrial respiration upstream of complex IV [110]. Interestingly, in APL cell lines, increased catalase expression has been shown to correlate with ATO resistance [111]. Although ATO has been shown to work in concert with high-dose ascorbate, killing AML and APL blasts while leaving HSCs intact [112], ATO was not effective at treating non-APL forms of AML [113].

There are also several plant-derived compounds that exhibit anti-LSC properties, likely by targeting critical mechanisms of redox balance. These molecules include parthenolide, triptolide, cyclopamine, resveratrol, and avocatin B [114]. Mechanistically, parthenolide and its soluble analogue dimethylamino parthenolide stimulate superoxide anion generation by activating NADH oxidase, followed by activation of the kinase JNK and NK$\kappa B$ [115]. Interestingly, a rationally designed regimen consisting of parthenolide, 2-deoxy-D-glucose, and temsirolimus has been shown to selectively target LSCs with little to no apparent effect on normal HSCs [116]. The anti-leukemic activity of this regimen is associated with its strong ability to induce oxidative stress without activating the compensatory responses in AML cells [116]. ROS-mediated dimerization of Bax, a pro-apoptotic member of the Bcl-2 protein family, and oxidation of cardiolipin trigger the release of cytochrome $c$ into the cytosol, and has been proposed as oxidative stress-based mechanisms of apoptotic activation [117]. Another naturally occurring compound, cyclopamine, inhibits hedgehog signaling and induces apoptosis in AML CD34 ${ }^{+}$ blasts [114], and directly inhibits OxPhos in lung tumors [118]. Avocatin B induces ROS-dependent, mitochondria-mediated apoptosis in AML cells, as well as inhibits fatty acid oxidation. It also synergizes with cytarabine/doxorubicin to induce leukemia cell death [114].

Increasing ROS level beyond the capacity of antioxidant defense can cause several types of cell death in AML [101, 102, 119]. Apoptosis is the most common type of cell death resulting from increased ROS production [120]. ROS may activate both mitochondrial (intrinsic) and death receptor (extrinsic) pathways of apoptosis. Mitochondria-derived ROS are able to target mtDNA, disrupt respiratory chain function, lead to loss of mitochondrial membrane potential, impair ATP synthesis, and cause the release of cytochrome $c$ due to mitochondrial outer membrane permeabilization [121, 122].

In addition to apoptosis, elevated ROS in AML may also induce ferroptosis [123]. Ferroptosis is an irondependent programmed cell death pathway caused by the failure of glutathione-dependent antioxidant defense and unregulated lipid peroxidation [124]. This has implications for AML therapy. For example, low doses of erastin (ferroptosis inducer) enhance the anti-cancer activity of cytarabine or doxorubicin in AML cells [123]. Lastly, necroptosis as a type of cell death is frequently associated with ROS generation in AML [120]. Death 
receptor activators (TNF $\alpha$, FasL) can induce mitochondrial and non-mitochondrial ROS generation, followed by activation of ASK1 (apoptosis signal-regulating kinase 1) and p38 MAPK (mitogen-activated protein kinase), which results in caspase-independent AML cell death [121, 125].

One limitation of this approach, at least in theory, is that the increased ROS will contribute to genomic instability that may increase the probability of treatment resistance, with the thought being that any cells that do not develop resistance will perish, leaving only the resistant cells to divide [126]. In addition, AML cells are not the only cells that are very sensitive to ROS; HSCs also exhibit strong sensitivity and it would be difficult to kill the AML cells without also doing considerable, perhaps irreparable, damage to the healthy HSCs.

\section{Mitochondrial priming and $\mathrm{BCl}-2$ protein family}

Another key requirement for the proliferation of AML LSCs and blasts is the release from apoptotic activation. Generally, in AML, this is achieved by the overexpression of pro-survival Bcl-2 family proteins, including Bcl$\mathrm{X}_{\mathrm{L}}, \mathrm{Mcl}-1$, and Bcl-2 itself [127]. The anti-apoptotic Bcl2 proteins are members of a larger superfamily of proteins named after $\mathrm{Bcl}-2$, the founding member. Proteins in the family typically share Bcl-2-like homology domains 1-4 (BH1-BH4), and include both pro- and antiapoptotic members, although there is a third group, possessing only the $\mathrm{BH} 3$ domain, that are also proapoptotic [128, 129]. Members of this family trigger apoptosis by intercalating into the outer membrane, increasing its permeability, releasing pro-apoptotic factors, and activating the caspases responsible for a commitment to cell death [130]. Insertion into the membrane appears to, at least partially, depend on whether Bcl-2family members have oligomerized via their $\mathrm{BH} 3$ domains. As reviewed elsewhere [128, 131], conventional cytotoxic chemotherapy often activates apoptosis via mitochondrial permeabilization using Bcl-2-family members.

For these reasons, it has become common to target the $\mathrm{BH} 3$ domain of the anti-apoptotic members of the Bcl-2 family with small molecule drugs [132]. The best known and most successful BH3-domain targeting drugs include obatoclax, ABT-737, and an orally available derivative called ABT-263 (also known as navitoclax), which target Bcl-2, Blc- $\mathrm{X}_{\mathrm{L}}$, and Bcl-W, and ABT-199 (also known as venetoclax), which targets Bcl-2 [86, 132-135]. Venetoclax has become the most clinically effective BH3-targeting drug approved by the FDA for leukemia treatment and has received FDA approval in several different contexts [136-138]. A comprehensive review of venetoclax's use and function has recently been published [139], so it will not be discussed in depth here.

Although venetoclax has demonstrated encouraging results in targeting $\mathrm{Bcl}-2$, resistance can still develop. The most common cause of this is stabilization of Mcl-1 [140]. This, along with the fact that Mcl-1 is essential for the development and survival of AML cells, has led to the development of selective Mcl-1 inhibitors [141]. Sharon et al. used CRISPR knockout screen to determine that ribosome-targeting antibiotics such as tedizolid can overcome venetoclax resistance by suppressing mitochondrial translation and respiration, and activating the cellular stress response [142]. Moreover, the addition of tedizolid to azacitidine and venetoclax further enhanced the killing of resistant AML cells in vitro and in vivo [142].

Although mitochondrial permeabilization is sometimes considered to be an irreversible commitment, there is evidence that this may be an oversimplification. For example, it has been reported that not all mitochondria undergo permeabilization simultaneously [143, 144]. In addition, it is possible to measure the differences in mitochondrial permeabilization, which revealed that these differences, termed "priming", are associated with sensitivity to chemotherapy [145]. Interestingly, lower priming is also associated with resistance to chemotherapy [145]. Together, these phenomena suggest that targeting mitochondrial permeability may be an effective method of treating AML in general.

\section{Mitophagy as a target for AML therapy}

Even in healthy cells, the production of ROS is associated with damage to mitochondria. This damage reduces their effective function and can trigger apoptosis or macroautophagic mitochondrial recycling (also known as mitophagy). Under normal circumstances, mitochondria undergo frequent fission and fusion events that, by means yet unknown, sort intact and damaged components so that the former can be retained while the latter are recycled [146].

Although the sorting mechanisms remain unclear, the events coming after have begun to be illuminated. Currently, the best-known regulators of mitophagy are the PTEN-induced kinase 1 (PINK1) and the E3 ubiquitin ligase Parkin, which are conserved at least as far back as the nematode Caenorhabditis elegans. While mitochondria are healthy, PINK1 is imported into mitochondria, where it is immediately cleaved by resident proteases [147]. Under stress conditions or loss of mitochondrial membrane potential (i.e., if mitochondrial import is blocked), PINK1 accumulates on the surface of mitochondria, phosphorylating itself and Parkin [148-150]. Once recruited, Parkin catalyzes the ubiquitination that 
allows mitochondria to be recognized by autophagosomes [146].

Broadly speaking, the idea of autophagy-dependent cell death or, more specifically, mitophagy-dependent cell death, remains controversial [151]. On the one hand, the ability to remove defective mitochondria (mitigating ROS, preventing the activation of apoptosis, and providing building blocks for cell division) makes mitophagy an important tool for leukemic progression. Knockdown of autophagic genes involved in mitochondrial clearance, including BNIP3L/Nix and SQSTM1/p62 also sensitizes cells to mitochondria-targeted therapies [152, 153], arguing that these genes promote cancer cell survival. LSCs have also recently been argued to leverage mitophagy in an attempt to maintain stemness [154]. Mitophagy also promotes survival in the hypoxic conditions that exist in the bone marrow microenvironment [155]. Inhibiting autophagy in these conditions decreased in vivo tumor burden and enhanced apoptosis [155].

In contrast, there is some evidence that mitophagy can limit the growth of cancer cells. For example, inhibiting the activity of complex I in melanoma cells depolarizes the mitochondrial membrane, upregulating ROS, and causes mitophagy-dependent cell death activation [156]. Another report has demonstrated that a trihydroxyphenyl alkone also depolarizes the mitochondrial membrane and triggers autophagic death of melanoma cells [157]. Additionally, loss of autophagy in vivo is associated with a glycolytic shift and more aggressive growth of myelocytes [158]. Sodium selenite, a known activator of mitophagy, triggers programmed cell death in malignant glioma cells via an autophagy-dependent manner [159]. Disruption of autophagy genes is also associated with overproliferation in several solid tumors, further strengthening this connection [160,161].

Critically, this included HSCs, where deletion of Atg7 or Atg5 resulted in myeloproliferation [158, 162]. Interestingly, these proliferated cells seemed to have lost their stemness and were not able to serve as LSCs, perhaps indicating another key difference between LSCs and myeloblasts. A statistical analysis has demonstrated that mutation of autophagy-related genes occurs more frequently in AML than would be expected by chance [158].

Perhaps most promisingly, there is at least one report that appears to directly target leukemia using activation of mitophagy [163]. The authors of this report demonstrated that FLT3-ITD AML cells were deficient in $C_{18}$ ceramides, which have been associated with apoptosisindependent autophagic cell death [164]. The authors observed that the FLT3-ITD mutation reduced the function of the CerS1 gene (which is responsible for the biosynthesis of $\mathrm{C}_{18}$ ceramides) and that disrupting FLT3 improved $\mathrm{C}_{18}$ synthesis, which localized to mitochondria, recruited autophagic machinery, and triggered autophagy [163]. Normal markers of apoptosis and necrosis were not observed and pan-caspase and necroptotic inhibitors did not affect FLT3-ITD-targeted rescue. In contrast, bafilomycin $\mathrm{A} 1$, which prevents acidification of the autophagolysosome, prevented the cytotoxicity that was triggered by the kinase inhibitors sorafenib, crenolanib, or quizartinib [163]. The report also included evidence that a synthetic ceramide analog could potentiate mitophagy and kill tumor cells by overcoming their resistance to kinase inhibitors. Importantly, this effect was specific to leukemia cells and was observed in a murine PDX AML model, supporting both the potential of this approach and of this particular therapy.

Ultimately, the utility of mitophagy as a tool in the arsenal of anti-cancer treatments may be limited to certain genetic causes of AML or to certain populations of cells, such as myeloblasts or LSCs, but further study of this possibility will be essential to make this determination.

\section{Conclusions and future perspectives}

Over the last three decades, it has become clear that AML cells gain considerable metabolic plasticity during their escape from bone marrow niches and their transitions to proliferating cancer cells. Mitochondria are a central hub for many of these pathways, and the dependency of these cells on mitochondrial function and health is quickly becoming a hallmark of AML, and potentially their Achilles' heel. It is not surprising that many agents targeting mitochondria and mitochondrial function are currently being investigated in clinical trials or have already been approved by the US FDA for treatment of patients (summarized in Tables 1 and 2, Fig. 1).

One of the most promising future directions in AML therapy is the search for drug combinations with synergistic activity. The utility of this approach has been borne out with the classic example of cytarabine and daunorubicin [210, 211]. These AML-targeted combinations may be comprised of drugs from the same class, such as the pairing of various anthracyclines with cytarabine, or from drugs with different mechanisms of action, such as quizartinib and azacitidine, which inhibit FTL3 and DNA methyltransferase activities, respectively [288, 289]. Since monotherapies are known to result in the development of compensatory mechanisms and/or resistance, the rational design of drug regimens is of great importance. A carefully considered approach can also be more effective and comprehensive than traditional highthroughput searches $[116,290]$. For example, the sesquiterpene lactone parthenolide was found to target the redox balance in AML cells, but also led to compensatory activity from the Nrf2 and pentose phosphate pathways [116]. However, by combining parthenolide with 
Table 1 Mitochondria-targeted chemotherapeutics (mitocans) as monotherapy against AML

\begin{tabular}{|c|c|c|c|c|c|}
\hline $\mathrm{N}$ & Drugs & $\begin{array}{l}\text { Targets/inhibition related to } \\
\text { mitochondria }\end{array}$ & $\begin{array}{l}\text { AML subgroup if } \\
\text { applicable }\end{array}$ & $\begin{array}{l}\text { Level 1: } \\
\text { preclinical } \\
\text { (in vitro, PDX) }\end{array}$ & $\begin{array}{l}\text { Level 2: clinical trials/ } \\
\text { studies in AML patients }\end{array}$ \\
\hline \multicolumn{6}{|c|}{ 1. DNA-targeted agents/cytotoxic chemotherapy } \\
\hline 1.1.1 & Cytarabine & $\begin{array}{l}\text { DNA polymerase, topoisomerase } \| \text {, } \\
\text { incorporation into DNA/RNA }\end{array}$ & AML & {$[165]$} & [166] \\
\hline 1.1 .2 & $\begin{array}{l}\text { Doxorubicin/idarubicin/ } \\
\text { daunorubicin }\end{array}$ & & & & [167] \\
\hline 1.1.3 & Mitoxanthrone & & & [168] & [169] \\
\hline 1.1 .4 & Etoposide & & & {$[170]$} & Phase II [171] \\
\hline 1.2 & ddC/alovudine & $\begin{array}{l}\text { Mitochondrial DNA polymerase } \gamma \text {, } \\
\text { OxPhos }\end{array}$ & AML & {$[172,173]$} & - \\
\hline 1.3 & Bleomycin & mtDNA, OxPhos & AML & {$[174]$} & - \\
\hline \multicolumn{6}{|c|}{ 2. Bcl-2 family inhibitors } \\
\hline 2.1 .1 & Navitoclax & $\mathrm{BCl}-2$ & AML & {$[72]$} & - \\
\hline 2.1.2 & Obatoclax & & & {$[175]$} & - \\
\hline 2.1.3 & Venetoclax & & $\begin{array}{l}\text { R/R AML/unfit for intensive } \\
\text { therapy }\end{array}$ & {$[176,177]$} & Phase II [138] \\
\hline \multirow[t]{2}{*}{2.2} & Obatoclax & Pan Bcl-2 & de novo AML & {$[178]$} & Phase I/II [179] \\
\hline & & & $\mathrm{R} / \mathrm{R} \mathrm{AML}$ & & Phase I [180] \\
\hline 2.3.1 & S63845/S64315 & Mcl1 & AML & [181] & Phase I (NCT02979366) \\
\hline 2.3 .2 & A-1210477 & & & [182] & - \\
\hline 2.3 .3 & AZD5991 & & R/R AML & [183] & Phase I/II (NCT03218683) \\
\hline 2.4 & a-TOS & $\begin{array}{l}\text { Bid cleavage, complex I, ROS } \\
\text { production }\end{array}$ & APL & {$[184,185]$} & - \\
\hline \multicolumn{6}{|c|}{ 3. Agents targeting mitochondrial metabolism } \\
\hline 3.1 .1 & 2-DG & Hexokinase II & AML, FLT3-ITD AML & {$[34,43]$} & - \\
\hline 3.1 .2 & 3-BP & $\begin{array}{l}\text { Hexokinase II, OxPhos, ROS } \\
\text { production }\end{array}$ & & {$[186,187]$} & - \\
\hline 3.1 .3 & $3-\mathrm{BrOP}$ & Hexokinase II & & [43] & - \\
\hline 3.2 & 3-PO & 6-Phosphofructo-1-kinase & AML & {$[37]$} & - \\
\hline 3.3 .1 & CPI-613 & PDK, OxPhos & AML & [188] & Phase I [188] \\
\hline 3.3 .2 & DAP & & & [189] & - \\
\hline 3.4 & Enasidenib & $\mathrm{IDH} 2^{\text {mut }}$ & $\mathrm{IDH} 2^{\text {mut }} \mathrm{R} / \mathrm{R} \mathrm{AML}$ & [190] & $\begin{array}{l}\text { Phase } 1 / / I \text { [191] } \\
\text { FDA-approved }\end{array}$ \\
\hline 3.5 .1 & Telaglenastat & Glutaminase & AML & [192] & Phase I (NCT02071927) \\
\hline 3.5 .2 & BPTES & & $\begin{array}{l}\text { AML with } \mathrm{IDH} 1 / 2 \\
\text { mutations }\end{array}$ & {$[62]$} & - \\
\hline 3.6 .1 & ADI-PEG 20 & Arginine depletion & $\mathrm{R} / \mathrm{R}$ or poor-risk $\mathrm{AML}$ & [193] & Phase II (NCT01910012) \\
\hline & ВСТ-100 & & Pediatric R/R AML & [194] & Phase I/II (NCT03455140) \\
\hline
\end{tabular}


Table 1 Mitochondria-targeted chemotherapeutics (mitocans) as monotherapy against AML (Continued)

\begin{tabular}{|c|c|c|c|c|c|}
\hline $\mathbf{N}$ & Drugs & $\begin{array}{l}\text { Targets/inhibition related to } \\
\text { mitochondria }\end{array}$ & $\begin{array}{l}\text { AML subgroup if } \\
\text { applicable }\end{array}$ & $\begin{array}{l}\text { Level 1: } \\
\text { preclinical } \\
\text { (in vitro, PDX) }\end{array}$ & $\begin{array}{l}\text { Level 2: clinical trials/ } \\
\text { studies in AML patients }\end{array}$ \\
\hline 3.7 & L-asparaginase & $\begin{array}{l}\text { Asparagine depletion, glutamine } \\
\text { uptake inhibition }\end{array}$ & AML & {$[195]$} & Phase I (NCT02283190) \\
\hline 3.8 .1 & Etomoxir & $\mathrm{FAO}(\mathrm{CPT} 1)$ & AML & {$[21]$} & - \\
\hline 3.8 .2 & Ranolazine & FAO (3-ketoacyl CoA thiolase) & & & \\
\hline 3.8 .3 & ST1326 & $\mathrm{FAO}(\mathrm{CPT} 1)$ & & [196] & \\
\hline 3.8 .4 & Avocatin B & $\begin{array}{l}F A O, \text { ROS production, cytochrome } \\
\text { c release }\end{array}$ & & [197] & \\
\hline
\end{tabular}

4. Agents targeting OxPhos and/or mitochondrial biogenesis/respiration

\begin{tabular}{|c|c|c|c|c|c|}
\hline 4.1 & Tigecycline & $\begin{array}{l}\text { Mitochondrial translation, } \\
\text { mitochondrial biogenesis }\end{array}$ & AML & {$[65]$} & Phase I [73] \\
\hline 4.2 .1 & Metformin & $\begin{array}{l}\text { Complex I, mitochondrial oxygen } \\
\text { consumption }\end{array}$ & $\mathrm{AML}$ & [79] & - \\
\hline 4.2 .2 & IACS-010759 & & R/R AML & [81] & Phase I (NCT02882321) \\
\hline 4.2 .3 & Rotenone & & AML & {$[35]$} & - \\
\hline 4.3 & A2-32-01 & $\begin{array}{l}\text { Mitochondrial protease ClpP, } \\
\text { Complex II }\end{array}$ & AML & [90] & - \\
\hline 4.4 & Cysteinase & Complex II & AML & [198] & - \\
\hline 4.5 & Antimycin & Complex III & AML & {$[66]$} & - \\
\hline 4.6.1 & Isobavachalcone & Pyrimidine biosynthesis (DHODH) & AML & [199] & - \\
\hline 4.6 .2 & PTC299 & & $\begin{array}{l}\text { R/R AML/AML patients } \\
\text { unfit for standard therapy }\end{array}$ & [200] & Phase I (NCT03761069) \\
\hline 4.6 .3 & ASLAN003 & & & [201] & Phase II (NCT03451084) \\
\hline 4.6 .4 & BAY 2402234 & & $\mathrm{AML}$ & [202] & Phase I (NCT03404726) \\
\hline Agen & ts inducing ROS produc & tion/targeting MPTP & & & \\
\hline 5.1 & Arsenic trioxide & $\begin{array}{l}\text { ANT, ROS production, MMP, DNA } \\
\text { damage }\end{array}$ & $\begin{array}{l}\text { De novo AML, secondary } \\
\text { AML, R/R AML }\end{array}$ & [109] & Phase II [203] \\
\hline & & & APL & & Phase I/II (NCT00008697) \\
\hline 5.2 & Lonidamine & ANT, OxPhos (complex II) & AML & {$[67,204,205]$} & - \\
\hline 5.3 & Parthenolide & ROS production, NF-kB inhibition & AML & [206] & - \\
\hline 5.4 & $\begin{array}{l}\text { Triptolide (minnelide as } \\
\text { a soluble prodrug) }\end{array}$ & ROS production, Mcl1, MMP & AML & {$[207]$} & Phase I/lb (NCT03760523) \\
\hline 5.5 & Resveratrol & NF-kB, apoptosis induction & AML & [208] & - \\
\hline Mitoc & chondrial uncouplers & & & & \\
\hline 6 & CCCP & MMP & AML & [67] & - \\
\hline 6.2 & $\begin{array}{l}\text { Dichlorophenyl urea } \\
\text { (SR4, SR9) }\end{array}$ & MMP & AML & [209] & - \\
\hline
\end{tabular}

the anti-glycolytic 2-deoxy-D-glucose and the mTOR inhibitor temsirolimus, effective AML eradication was achieved [116]. Similarly, classic chemotherapeutics can be paired with novel classes of treatments like autophagic inhibitors or miRNA mimics/antisense to achieve a synergistic therapeutic effect [291, 292].

Where AML was once one of the most lethal and most rapidly developing cancers, the identification and 
Table 2 Mitochondria-targeted chemotherapeutics (mitocans) in synergistic combinations against AML

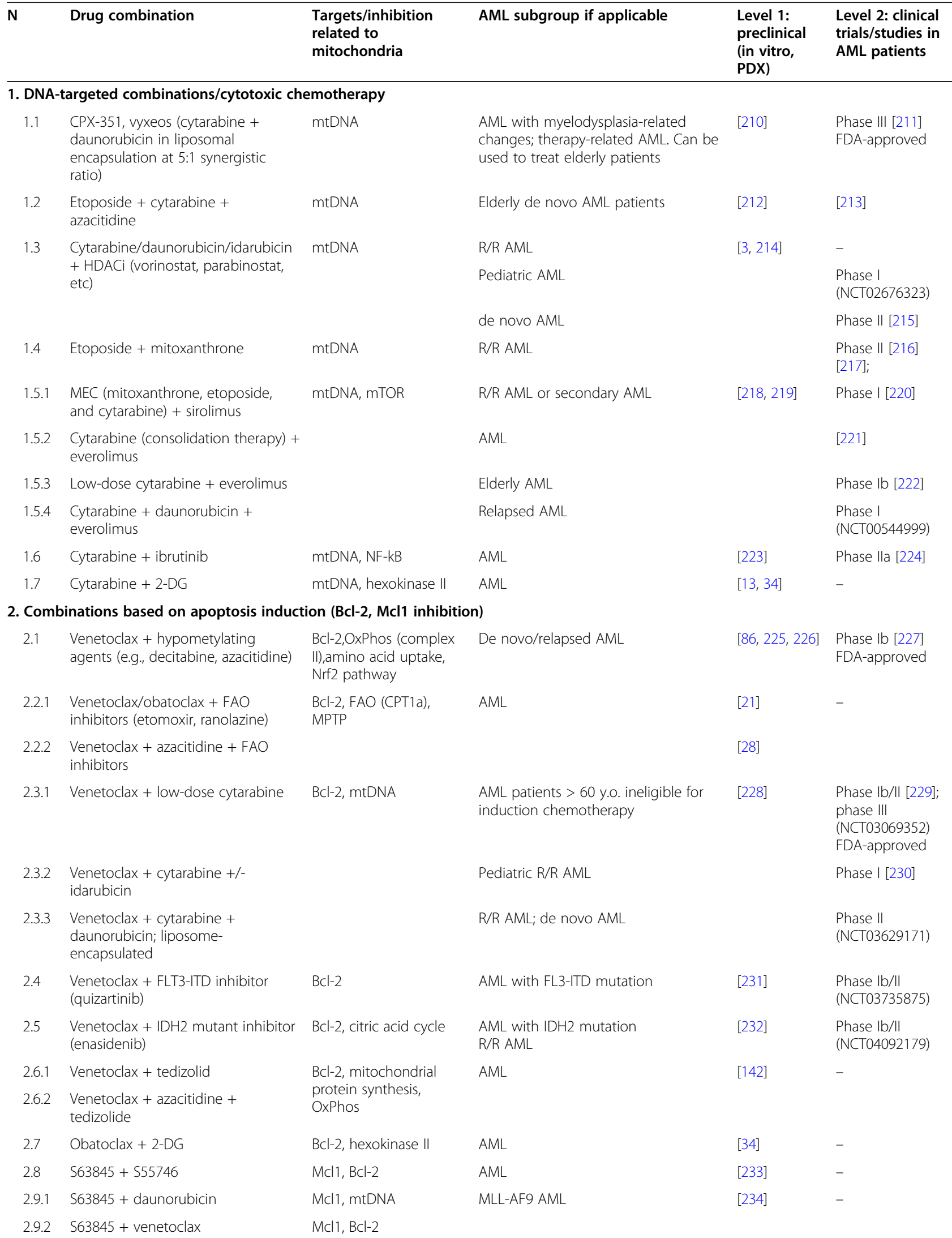


Table 2 Mitochondria-targeted chemotherapeutics (mitocans) in synergistic combinations against AML (Continued)

\begin{tabular}{|c|c|c|c|c|c|}
\hline $\mathrm{N}$ & Drug combination & $\begin{array}{l}\text { Targets/inhibition } \\
\text { related to } \\
\text { mitochondria }\end{array}$ & AML subgroup if applicable & $\begin{array}{l}\text { Level 1: } \\
\text { preclinical } \\
\text { (in vitro, } \\
\text { PDX) }\end{array}$ & $\begin{array}{l}\text { Level 2: clinical } \\
\text { trials/studies in } \\
\text { AML patients }\end{array}$ \\
\hline 2.10 .1 & A-1210477 + venetoclax & $\mathrm{Mcl} 1, \mathrm{BCl}-2$ & AML & {$[140]$} & - \\
\hline 2.10 .2 & UNBS1450 + venetoclax & & & {$[235]$} & \\
\hline 2.11 & AZD5991 + venetoclax & $\mathrm{Mcl} 1, \mathrm{BCl}-2$ & AML & [183] & $\begin{array}{l}\text { Phase I/II } \\
\text { (NCT03218683) }\end{array}$ \\
\hline 2.12 & Obatoclax + HDACi & $\begin{array}{l}\text { Bcl-2,autophagy } \\
\text { induction }\end{array}$ & $\mathrm{AML}$ & {$[236]$} & - \\
\hline \multicolumn{6}{|c|}{ 3. Combinations targeting mitochondrial metabolism } \\
\hline 3.1 & $\begin{array}{l}\text { CPI- } 613+\text { mitoxanthrone }+ \text { high- } \\
\text { dose cytarabine }\end{array}$ & PDK, mtDNA & R/R AML & [48] & Phase I [48] \\
\hline 3.2 & Telaglenastat + venetoclax & Glutaminase, $\mathrm{BCl}-2$ & AML & [59] & - \\
\hline 3.3.1 & Telaglenastat + arsenic trioxide & \multirow{2}{*}{$\begin{array}{l}\text { Glutaminase, ROS } \\
\text { production, MMP }\end{array}$} & \multirow[t]{2}{*}{ AML } & \multirow[t]{2}{*}[61]{} & \multirow[t]{2}{*}{ - } \\
\hline 3.3.2 & Telaglenastat + homoharringtonine & & & & \\
\hline 3.4 & Telaglenastat + azacitidine & Glutaminase & $\mathrm{AML}$ & {$[237]$} & $\begin{array}{l}\text { Phase I } \\
\text { (NCT02071927) }\end{array}$ \\
\hline 3.5 & $\begin{array}{l}\text { Telaglenastat + AC220 (FLT3 } \\
\text { inhibitor) }\end{array}$ & $\begin{array}{l}\text { Glutaminase, ROS } \\
\text { production }\end{array}$ & FLT3-mutated AML & {$[238]$} & - \\
\hline 3.6.1 & $\begin{array}{l}\text { ADI-PEG } 20 \text { (pegylated arginase) + } \\
\text { cytarabine }\end{array}$ & $\begin{array}{l}\text { Arginine depletion, } \\
\text { mtDNA }\end{array}$ & $\mathrm{AML}$ & [193] & $\begin{array}{l}\text { Phase I } \\
\text { (NCT02875093) }\end{array}$ \\
\hline 3.6 .2 & $\begin{array}{l}\text { BCT-100 (pegylated arginase) + } \\
\text { cytarabine }\end{array}$ & & & [194] & - \\
\hline 3.7.1 & $\begin{array}{l}\text { Asparaginase }+ \text { low/high-dose } \\
\text { cytarabine }\end{array}$ & $\begin{array}{l}\text { Asparagine depletion, } \\
\text { mtDNA }\end{array}$ & $\begin{array}{l}\text { R/R AML/Elderly AML patients > } 65 \\
\text { y.o. }\end{array}$ & & $\begin{array}{l}\text { Phase II } \\
\text { (NCT01810705) } \\
\text { [239]; }\end{array}$ \\
\hline 3.7 .2 & $\begin{array}{l}\text { Asparaginase }+ \text { high-dose cytara- } \\
\text { bine }+ \text { mitoxanthrone }\end{array}$ & & & & [240] \\
\hline 3.8 & $\begin{array}{l}\text { Etomoxir (FAO inhibitor) + } \\
\text { cytarabine }\end{array}$ & CPT1a, MPTP, mtDNA & AML & {$[21,68]$} & - \\
\hline 3.9 .1 & Etomoxir + arsenic trioxide & $\begin{array}{l}\text { CPT1a, MPTP, ROS } \\
\text { production }\end{array}$ & $\mathrm{AML}, \mathrm{APL}$ & [241] & - \\
\hline 3.9 .2 & $\begin{array}{l}\text { Etomoxir + arsenic trioxide + 2-DG/ } \\
\text { lonidamine }\end{array}$ & $\begin{array}{l}\text { CPT1a, MPTP, ROS } \\
\text { production, Hexokinase } \\
\|\end{array}$ & & & \\
\hline 3.10 & Avocatin B + cytarabine & $\begin{array}{l}\text { FAO, ROS production, } \\
\text { mtDNA }\end{array}$ & AML & {$[242]$} & - \\
\hline \multicolumn{6}{|c|}{ 4. Combinations targeting OxPhos } \\
\hline 4.1 .1 & Metformin $+2-D G$ & Complex I, hexokinase II & AML & {$[79]$} & - \\
\hline 4.1 .2 & IACS-010759 + 2-DG & & & {$[35]$} & - \\
\hline 4.1 .3 & Rotenone + 2-DG & & & & \\
\hline 4.2 & Metformin + sorafenib & Complex I, mTOR & FLT3-mutated AML & {$[243]$} & - \\
\hline 4.3 & Metformin + 6-BT & $\begin{array}{l}\text { Complex I, STAT5, } \\
\text { glycolysis }\end{array}$ & FLT3-mutated AML & {$[244]$} & - \\
\hline 4.4 & Metformin + cytarabine & $\begin{array}{l}\text { Complex I, mTOR, } \\
\text { mtDNA }\end{array}$ & R/R AML & {$[245]$} & $\begin{array}{l}\text { Phase I } \\
\text { (NCT01849276) }\end{array}$ \\
\hline 4.5 & $\begin{array}{l}\text { Metformin + NSAIDs (diflunisal + } \\
\text { diclofenac) }\end{array}$ & Complex I & AML & {$[80]$} & - \\
\hline 4.6 & $C C C P+2-D G$ & MMP, hexokinase II & AML & {$[35,67]$} & - \\
\hline 4.7 & IACS-010759 + vinorelbine & Complex I, OxPhos & AML & {$[35]$} & - \\
\hline
\end{tabular}


Table 2 Mitochondria-targeted chemotherapeutics (mitocans) in synergistic combinations against AML (Continued)

\begin{tabular}{|c|c|c|c|c|c|}
\hline $\mathrm{N}$ & Drug combination & $\begin{array}{l}\text { Targets/inhibition } \\
\text { related to } \\
\text { mitochondria }\end{array}$ & AML subgroup if applicable & $\begin{array}{l}\text { Level 1: } \\
\text { preclinical } \\
\text { (in vitro, } \\
\text { PDX) }\end{array}$ & $\begin{array}{l}\text { Level 2: clinical } \\
\text { trials/studies in } \\
\text { AML patients }\end{array}$ \\
\hline 4.8 & $\begin{array}{l}\text { IACS-010759 + doxorubicin + } \\
\text { cytarabine }\end{array}$ & Complex I, mtDNA & AML & {$[246]$} & - \\
\hline 4.9 & Antimycin + 3-BrOP & $\begin{array}{l}\text { Complex III, glycolysis, } \\
\text { ATP depletion }\end{array}$ & AML & {$[87]$} & - \\
\hline 4.10 & $\begin{array}{l}\text { Oligomycin + tyrosine kinase } \\
\text { inhibitors }\end{array}$ & $\begin{array}{l}\text { Complex V, ROS } \\
\text { production }\end{array}$ & FLT3-mutated AML & {$[89]$} & - \\
\hline 4.11 & Isobavachalcone + doxorubicin & DHODH, mtDNA & AML & [199] & - \\
\hline 4.12 & ASLAN003 + azacitidine & $\mathrm{DHODH}$ & AML patients > 60 y.o. & & $\begin{array}{l}\text { Phase II } \\
\text { (NCT03451084) }\end{array}$ \\
\hline \multicolumn{6}{|c|}{ 5. Combinations inducing ROS generation/targeting mitochondrial membrane complexes } \\
\hline 5.1 & Diamide + doxorubicin & UCP2, mtDNA & AML & [247] & - \\
\hline 5.2 & $\begin{array}{l}\text { Arsenic trioxide }+ \text { high-dose } \\
\text { ascorbate }\end{array}$ & $\begin{array}{l}\text { ANT, MMP,ROS } \\
\text { production }\end{array}$ & $\begin{array}{l}\text { APL (more promising results than in } \\
\text { AML) }\end{array}$ & [112] & $\begin{array}{l}\text { Phase II } \\
\text { (NCT00184054) } \\
{[113,248] ;}\end{array}$ \\
\hline 5.3 .1 & $\begin{array}{l}\text { Arsenic trioxide + decitabine/ } \\
\text { azacitidine }\end{array}$ & $\begin{array}{l}\text { ANT, MMP,ROS } \\
\text { production }\end{array}$ & AML & [249] & $\begin{array}{l}\text { Phase II } \\
\text { (NCT02190695) }\end{array}$ \\
\hline 5.3 .2 & $\begin{array}{l}\text { Arsenic trioxide }+ \text { decitabine/ } \\
\text { azacitidine }+ \text { ascorbate }\end{array}$ & & & & Phase I [250] \\
\hline 5.4 .1 & $\begin{array}{l}\text { Arsenic trioxide + low-dose } \\
\text { cytarabine }\end{array}$ & $\begin{array}{l}\text { ANT, MMP, ROS } \\
\text { production, mtDNA }\end{array}$ & AML patients $>60$ y.o. & & $\begin{array}{l}\text { Phase I/II [251]; } \\
\text { phase III } \\
\text { (NCT00513305) } \\
\text { [252]; }\end{array}$ \\
\hline 5.4 .2 & $\begin{array}{l}\text { Arsenic trioxide }+ \text { high-dose cytara- } \\
\text { bine }+ \text { idarubicin }\end{array}$ & & AML patients $<60$ y.o. & & Phase I [253] \\
\hline 5.5 & $\begin{array}{l}\text { Arsenic trioxide + mTOR inhibitors } \\
\text { (rapamycin) }\end{array}$ & $\begin{array}{l}\text { ANT, MMP, ROS } \\
\text { production, mTOR }\end{array}$ & $\begin{array}{l}\text { AML lacking t(15;17) translocation } \\
\text { (non-APL) }\end{array}$ & {$[254]$} & - \\
\hline 5.6 & $\begin{array}{l}\text { Arsenic trioxide }+ \text { proteasome } \\
\text { inhibitor bortezomib }\end{array}$ & $\begin{array}{l}\text { ANT, MMP, ROS } \\
\text { production, NF-kB, UPR } \\
\text { activation }\end{array}$ & AML, APL/relapsed APL & {$[255,256]$} & Phase II [257] \\
\hline 5.7 .1 & Arsenic trioxide + lonidamine & $\begin{array}{l}\text { ANT, MMP, ROS } \\
\text { production, mTOR, } \\
\text { glycolysis }\end{array}$ & AML & {$[258]$} & - \\
\hline 5.7 .2 & Arsenic trioxide $+3-B P$ & $\begin{array}{l}\text { ANT, MMP, ROS } \\
\text { production, glycolysis }\end{array}$ & AML & [186] & - \\
\hline 5.8 & Arsenic trioxide + DCA & $\begin{array}{l}\text { ANT, MMP, ROS } \\
\text { production, PDK, Mcl1 }\end{array}$ & AML, including FLT3-ITD, R/R AML & {$[259]$} & [259] \\
\hline 5.9 & Arsenic trioxide + ATRA & $\begin{array}{l}\text { ANT, MMP, ROS } \\
\text { production }\end{array}$ & APL & {$[260]$} & Phase III [261] \\
\hline 5.10 & Parthenolide + 2-DG+ temsirolimus & $\begin{array}{l}\text { ROS production, Nrf2, } \\
\text { PPP, mTOR, hexokinase } \\
\|\end{array}$ & AML & [116] & - \\
\hline 5.11 .1 & Parthenolide + ibrutinib & $\begin{array}{l}\text { ROS production, NF-kB, } \\
\text { mtDNA }\end{array}$ & AML & {$[223,262]$} & - \\
\hline 5.11 .2 & Daunorubicin + ibrutinib & & & & \\
\hline 5.12 & Triptolide + idarubicin & $\begin{array}{l}\text { ROS production, Nrf2, } \\
\text { HIF1a }\end{array}$ & AML & [263] & - \\
\hline 5.13 & Resveratrol + $\mathrm{HDACi}$ & $\begin{array}{l}\text { ROS production, DNA } \\
\text { damage }\end{array}$ & AML & {$[264]$} & - \\
\hline 5.14 & Cytarabine + PK11195 (PBR ligand) & mtDNA, MPTP & AML & {$[265]$} & - \\
\hline
\end{tabular}


Table 2 Mitochondria-targeted chemotherapeutics (mitocans) in synergistic combinations against AML (Continued)

\begin{tabular}{|c|c|c|c|c|c|}
\hline $\mathbf{N}$ & Drug combination & $\begin{array}{l}\text { Targets/inhibition } \\
\text { related to } \\
\text { mitochondria }\end{array}$ & AML subgroup if applicable & $\begin{array}{l}\text { Level 1: } \\
\text { preclinical } \\
\text { (in vitro, } \\
\text { PDX) }\end{array}$ & $\begin{array}{l}\text { Level 2: clinical } \\
\text { trials/studies in } \\
\text { AML patients }\end{array}$ \\
\hline 6.1 .1 & Bafilomycin A1 + cytarabine & \multirow{3}{*}{$\begin{array}{l}\text { Autophagy, ROS } \\
\text { production, MMP, } \\
\text { mtDNA }\end{array}$} & \multirow[t]{3}{*}{ AML } & {$[266]$} & \multirow[t]{3}{*}{-} \\
\hline 6.1 .2 & Chloroquine + cytarabine & & & & \\
\hline 6.1 .3 & Hydroxychloroquine + cytarabine & & & {$[267,268]$} & \\
\hline 6.2 & $\begin{array}{l}\text { Hydroxychloroquine }+ \\
\text { mitoxanthrone }+ \text { etoposide }\end{array}$ & Autophagy, mtDNA & $\mathrm{R} / \mathrm{R} \mathrm{AML}$ & & $\begin{array}{l}\text { Phase I } \\
\text { (NCT02631252) }\end{array}$ \\
\hline 6.3 & Chloroquine + arginase & $\begin{array}{l}\text { Autophagy, arginine } \\
\text { depletion }\end{array}$ & AML & [269] & - \\
\hline 6.4 & $\begin{array}{l}\text { Chloroquine }+\mathrm{HDACi} \text { (valproic } \\
\text { acid/ vorinostat) }\end{array}$ & $\begin{array}{l}\text { Autophagy, } \\
\text { accumulation of } \\
\text { ubiquitinated proteins }\end{array}$ & $\mathrm{t}(8 ; 21)$-mutated AML & {$[270]$} & - \\
\hline 6.5 & ROC-325 + azacitidine & Autophagy & AML & {$[271]$} & - \\
\hline 6.6 .1 & SBI-0206965 + cytarabine & \multirow{3}{*}{$\begin{array}{l}\text { ULK1 (autophagy), ROS } \\
\text { production, DNA } \\
\text { damage, mtDNA/BCl-2 }\end{array}$} & \multirow[t]{3}{*}{ AML } & \multirow[t]{2}{*}[272,273]{} & \multirow[t]{3}{*}{-} \\
\hline 6.6 .2 & SBI-0206965 + venetoclax & & & & \\
\hline 6.6 .3 & SBI-0206965 + daunorubicin & & & {$[274]$} & \\
\hline 6.7 .1 & JQ1 + daunorubicin & \multirow{2}{*}{$\begin{array}{l}\text { BET-bromodomain } \\
\text { proteins (S100A8/9, } \\
\text { BRD4), mtDNA }\end{array}$} & \multirow[t]{2}{*}{ AML } & {$[275]$} & \multirow[t]{2}{*}{-} \\
\hline 6.7 .2 & JQ1 + cytarabine & & & {$[276]$} & \\
\hline 6.8 & Birabresib + venetoclax & $\begin{array}{l}\text { BET-bromodomain } \\
\text { proteins, Bcl-2 }\end{array}$ & AML & {$[277]$} & - \\
\hline 6.9 & LCL-461 + FLT3-inhibitor crenolanib & $\begin{array}{l}\text { Activation of ceramide- } \\
\text { dependent mitophagy }\end{array}$ & AML with FL3-ITD mutation & [163] & - \\
\hline 6.10 & TAK-165 + FLT3-inhibitor AC220 & Autophagy & AML with FL3-ITD mutation & {$[278]$} & - \\
\hline 6.11 & $\begin{array}{l}\text { Petromurin C + FLT3-inhibitor } \\
\text { gilteritinib }\end{array}$ & $\begin{array}{l}\text { Induction of early } \\
\text { autophagy and } \\
\text { apoptosis, Mcl1 }\end{array}$ & AML with FL3-ITD mutation & [279] & - \\
\hline \multicolumn{6}{|c|}{ 7. Combinations targeting mitochondria-related miRNAs } \\
\hline 7.1 & $\begin{array}{l}\text { miR-181a/b mimics + doxorubicin/ } \\
\text { daunorubicin/cytarabine }\end{array}$ & Mcl1, Bcl-2, mtDNA & AML & {$[280-282]$} & - \\
\hline 7.2 & $\begin{array}{l}\text { miR-15a/16-1 mimic + arsenic } \\
\text { trioxide }\end{array}$ & $\begin{array}{l}\text { UCP2, MMP, } \\
\text { cytochrome c release, } \\
\text { ROS production }\end{array}$ & AML & [283] & - \\
\hline 7.3 & miR-9 mimic + daunorubicin & ElF5A2, Mcl1, mtDNA & AML & [284] & - \\
\hline 7.4.1 & miR-29b mimic + cytarabine & Mcl1, mtDNA & AML & {$[285]$} & - \\
\hline 7.4 .2 & miR-29b mimic + decitabine & & & [286] & \\
\hline 7.5 & Antisense miR-32 + cytarabine & $\begin{array}{l}\text { Bim upregulation, } \\
\text { mtDNA }\end{array}$ & AML & [287] & - \\
\hline
\end{tabular}

development of effective treatments have made remission a common occurrence. These new approaches, like conventional chemotherapy, can be very effective at inducing remission, even complete remission. Also like conventional treatments, however, they must take into account the metabolic differences between AML myeloblasts and LSCs (such as the differences in energy production, mitochondrial turnover, and sensitivity to ROS) discussed above. As LSCs commonly persist after therapy and are a reservoir for relapse and resistance, it is crucial to continue to investigate these differences and identify new treatments that can specifically target LSCs without causing inappropriate damage to normal HSCs at the same time. Much of our understanding of LSC metabolism has only begun to appear within the last decade, making this an active and developing area of research that promises to lead to even greater improvements in the treatment of AML. When this knowledge is leveraged and these treatment gaps are filled, long-term remission will become commonplace and the promise of effective AML treatments will finally be fulfilled. 


\section{Abbreviations}

AKT: Protein kinase B (Akt); a-TOS: (+)Alpha-tocopheryl succinate; ALL: Acute lymphoblastic leukemia; AML: Acute myeloid leukemia; AMPK: AMP-activated protein kinase; ANT: Adenine nucleotide translocator; APL: Acute promyelocytic leukemia; Ara-C: Cytarabine; ATO: Arsenic trioxide; ATRA: Alltrans-retinoic acid; Bak1: BCl-2-antagonist/killer 1; Bcl-2: B cell lymphoma 2; BET: Bromodomain and extra-terminal domain; $\mathrm{BH}(1 / 2 / 3 / 4)$ : $\mathrm{BCl}-2$ homology domain 1/2/3/4; BRD4: Bromodomain-containing protein 4; CAC: Citric acid cycle; CCCP: Carbonyl cyanide m-chlorophenyl hydrazone; CerS1: Ceramide synthase 1; CPT1: Carnitine O-palmitoyltransferase 1; DAP: 2,2Dichloroacetophenone; DCA: Dichloroacetate; ddC: 2'3'-Dideoxycytidine; DHODH: Dihydroorotate dehydrogenase; EIF5A2: Eukaryotic translation initiation factor 5A-2; ETC: Electron transport chain; FAO: Fatty acid oxidation; FIS1: Mitochondrial fission 1 protein; FLT3: FMS-like tyrosine kinase 3; GSH: Reduced glutathione; HDACi: Histone deacetylases inhibitors; HIF1a: Hypoxia-inducible factor 1a; HSC: Hematopoietic stem cells; IDH: Isocytrate dehydrogenase; ITD: Internal tandem duplication; JNK: c-Jun N-terminal kinase; KRAS: K-Ras protein; LSC: Leukemia stem cells; MAPK: Mitogen-activated protein kinase; Mcl1: Myeloid cell leukemia 1; miRNA: MicroRNA; MDR: Multidrug resistance; MMP: Mitochondrial membrane potential; MOMP: Mitochondrial outer membrane permeabilization; MPTP: Mitochondrial permeability transition pore; mtDNA: Mitochondrial DNA; mTORC1: Mammalian target of rapamycin complex 1; NF-kB: Nuclear factor kappa B; NOX: NADH-oxidase; NSAI Ds: Nonsteroidal anti-inflammatory drugs; NRAS: Neuroblastoma RAS protein; Nrf2: Nuclear factor erythroid 2-related factor 2; OxPhos: Oxidative phosphorylation; PBMC: Peripheral blood mononuclear cells; PBR: Peripheral benzodiazepine receptor; PDC: Pyruvate dehydrogenase complex; PDK: Pyruvate dehydrogenase kinase; PDX: Patient-derived xenografts: PFK1: Phosphofructokinase-1; PFKFB: Phosphofructokinase-2/fructose bisphosphatase; PINK1: PTEN-induced kinase 1; PPP: Penthose phosphate pathway; ROS: Reactive oxygen species; R/R: Relapsed/refractory AML; TCGA: The Cancer Genome Atlas; UCP: Uncoupling protein; ULK1: Unc-51-like autophagy activating kinase 1; VDAC: Voltage-dependent anion-selective channel; 2-DG: 2-Deoxy-D-glucose; 2-HG: 2-hydroxyglutarate; 3-BP: 3bromopyruvate; 3-BrOP: 3-bromo-2-oxopropionate-1-propyl ester; 3-MA: 3methyladenine; 3-PO: 3-(3-pyridinyl)-1-(4-pyridinyl)-2-propen-1-one; 4HNE: 4hydroxy-3-nonenal

\section{Acknowledgements}

We thank Kirienko lab members for productive discussions.

\section{Authors' contributions}

SBP wrote the first draft with the help of JP. NVK revised the manuscript and wrote the final version. SBP, JP, and NVK contributed to and edited the final version of the manuscript. The author(s) read and approved the final manuscript.

\section{Funding}

The study was supported by grants from the Cancer Prevention and Research Institute of Texas (CPRIT award RR150044) and the NIH NIGMS (R35GM129294) to NVK.

\section{Availability of data and materials}

Not applicable.

\section{Declarations}

Ethics approval and consent to participate

Not applicable.

\section{Consent for publication}

Not applicable.

\section{Competing interests}

The authors declare that they have no competing interests.
Received: 11 January 2021 Accepted: 30 March 2021

Published online: 21 April 2021

\section{References}

1. Oran B, Weisdorf DJ. Survival for older patients with acute myeloid leukemia: a population-based study. Haematologica. 2012;97(12):1916-24. https://doi.org/10.3324/haematol.2012.066100.

2. Dombret H, Gardin C. An update of current treatments for adult acute myeloid leukemia. Blood. 2016;127(1):53-61. https://doi.org/10.1182/blood-2 015-08-604520.

3. Li Y, Wang Y, Zhou Y, Li J, Chen K, Zhang L, et al. Cooperative effect of chidamide and chemotherapeutic drugs induce apoptosis by DNA damage accumulation and repair defects in acute myeloid leukemia stem and progenitor cells. Clin Epigenetics. 2017;9(1):83. https://doi.org/10.1186/s1314 8-017-0377-8.

4. Döhner H, Estey EH, Amadori S, Appelbaum FR, Büchner T, Burnett AK, et al. Diagnosis and management of acute myeloid leukemia in adults: recommendations from an international expert panel, on behalf of the European LeukemiaNet. Blood. 2010;115(3):453-74. https://doi.org/10.1182/ blood-2009-07-235358.

5. Pollyea DA, Jordan CT. Why are hypomethylating agents or low-dose cytarabine and venetoclax so effective? Curr Opin Hematol. 2019;26(2):71-6. https://doi.org/10.1097/MOH.0000000000000485.

6. Alfayez M, Kantarjian H, Kadia T, Ravandi-Kashani F, Daver N. CPX-351 (vyxeos) in AML. Leuk Lymphoma. 2020;61(2):288-97. https://doi.org/10.1 080/10428194.2019.1660970.

7. Kucukyurt S, Eskazan AE. New drugs approved for acute myeloid leukaemia in 2018. Br J Clin Pharmacol. 2019:85(12):2689-93. https://doi.org/10.1111/ bcp.14105.

8. Hanekamp D, Cloos J, Schuurhuis GJ. Leukemic stem cells: identification and clinical application. Int J Hematol. 2017;105(5):549-57. https://doi.org/10.1 007/s12185-017-2221-5.

9. Kamel-Reid S, Dick JE. Engraftment of immune-deficient mice with human hematopoietic stem cells. Science. 1988;242(4886):1706-9. https://doi.org/1 $0.1126 /$ science. 2904703

10. Kamel-Reid S, Letarte M, Sirard C, Doedens M, Grunberger T, Fulop G, et al. A model of human acute lymphoblastic leukemia in immune-deficient SCID mice. Science. 1989;246(4937):1597-600. https://doi.org/10.1126/science.2 595371.

11. Lapidot T, Pflumio F, Doedens M, Murdoch B, Williams DE, Dick JE. Cytokine stimulation of multilineage hematopoiesis from immature human cells engrafted in SCID mice. Science. 1992;255(5048):1137-41. https://doi.org/1 $0.1126 /$ science.1372131.

12. Lapidot T, Sirard C, Vormoor J, Murdoch B, Hoang T, Caceres-Cortes J, et al. A cell initiating human acute myeloid leukaemia after transplantation into SCID mice. Nature. 1994;367(6464):645-8. https://doi.org/10.1038/367645a0.

13. Chen WL, Wang JH, Zhao AH, Xu X, Wang YH, Chen TL, et al. A distinct glucose metabolism signature of acute myeloid leukemia with prognostic value. Blood. 2014;124(10):1645-54. https://doi.org/10.1182/blood-2014-02554204.

14. Castro I, Sampaio-Marques B, Ludovico P. Targeting metabolic reprogramming in acute myeloid leukemia. Cells. 2019;8(9):967.

15. Pereira O, Teixeira A, Sampaio-Marques B, Castro I, Girão H, Ludovico P. Signalling mechanisms that regulate metabolic profile and autophagy of acute myeloid leukaemia cells. J Cell Mol Med. 2018;22(10):4807-17. https:// doi.org/10.1111/jcmm.13737.

16. Poulain L, Sujobert P, Zylbersztejn F, Barreau S, Stuani L, Lambert M, et al. High mTORC1 activity drives glycolysis addiction and sensitivity to G6PD inhibition in acute myeloid leukemia cells. Leukemia. 2017;31(11):2326-35. https://doi.org/10.1038/leu.2017.81.

17. Pei S, Minhajuddin M, Callahan KP, Balys M, Ashton JM, Neering SJ, et al. Targeting aberrant glutathione metabolism to eradicate human acute myelogenous leukemia cells. J Biol Chem. 2013;288(47):33542-58. https:// doi.org/10.1074/jbc.M113.511170.

18. Kato M, Minakami H, Kuroiwa M, Kobayashi Y, Oshima S, Kozawa K, et al. Superoxide radical generation and $\mathrm{Mn}$ - and $\mathrm{Cu}-\mathrm{Zn}$ superoxide dismutases activities in human leukemic cells. Hematol Oncol. 2003;21(1):11-6. https:// doi.org/10.1002/hon.699.

19. Rasool M, Faroog S, Malik A, Shaukat A, Manan A, Asif M, et al. Assessment of circulating biochemical markers and antioxidative status in acute 
lymphoblastic leukemia (ALL) and acute myeloid leukemia (AML) patients. Saudi J Biol Sci. 2015;22(1):106-11. https://doi.org/10.1016/.j.jbs.2014.09.002.

20. Shafat MS, Oellerich T, Mohr S, Robinson SD, Edwards DR, Marlein CR, et al. Leukemic blasts program bone marrow adipocytes to generate a protumoral microenvironment. Blood. 2017;129(10):1320-32. https://doi. org/10.1182/blood-2016-08-734798.

21. Samudio I, Harmancey R, Fiegl M, Kantarjian H, Konopleva M, Korchin B, et al. Pharmacologic inhibition of fatty acid oxidation sensitizes human leukemia cells to apoptosis induction. J Clin Invest. 2010;120(1):142-56. https://doi.org/10.1172/JC138942.

22. Dang L, White DW, Gross S, Bennett BD, Bittinger MA, Driggers EM, et al. Cancer-associated IDH1 mutations produce 2-hydroxyglutarate. Nature. 2009;462(7274):739-44. https://doi.org/10.1038/nature08617.

23. Figueroa ME, Abdel-Wahab O, Lu C, Ward PS, Patel J, Shih A, et al. Leukemic IDH1 and IDH2 mutations result in a hypermethylation phenotype, disrupt TET2 function, and impair hematopoietic differentiation. Cancer Cell. 2010; 18(6):553-67. https://doi.org/10.1016/j.ccr.2010.11.015.

24. Culp-Hill R, D'Alessandro A, Pietras EM. Extinguishing the embers: targeting AML metabolism. Trends Mol Med. 2021;27(4):332-44.

25. Kobayashi $\mathrm{Cl}$, Suda T. Regulation of reactive oxygen species in stem cells and cancer stem cells. J Cell Physiol. 2012;227(2):421-30. https://doi.org/10.1 002/jcp.22764

26. Wang Y, Liu Y, Malek SN, Zheng P. Targeting HIF1a eliminates cancer stem cells in hematological malignancies. Cell Stem Cell. 2011;8(4):399-411. https://doi.org/10.1016/j.stem.2011.02.006.

27. Jones CL, Stevens BM, D’Alessandro A, Reisz JA, Culp-Hill R, Nemkov T, et al. Inhibition of amino acid metabolism selectively targets human leukemia stem cells. Cancer Cell. 2019;35(2):333-5. https://doi.org/10.1016/j.ccell.2019. 01.013 .

28. Jones CL, Stevens BM, Culp-Hill R, Dalessandro A, Krug A, Goosman M, et al. Inhibition of fatty acid metabolism re-sensitizes resistant leukemia stem cells to venetoclax with azacitidine. Blood. 2019;134(Supplement_1):1272.

29. Kreitz J, Schönfeld C, Seibert M, Stolp V, Alshamleh I, Oellerich T, et al. Metabolic Plasticity of Acute Myeloid Leukemia. Cells. 2019;8(8):805.

30. Sánchez-Mendoza SE, Rego EM. Targeting the mitochondria in acute myeloid leukemia. Appl Cancer Res. 2017;37(1):22. https://doi.org/10.1186/ s41241-017-0022-z.

31. Fulda S, Galluzzi L, Kroemer G. Targeting mitochondria for cancer therapy. Nat Rev Drug Discov. 2010;9(6):447-64. https://doi.org/10.1038/nrd3137.

32. Azevedo-Silva J, Queirós O, Baltazar F, Ułaszewski S, Goffeau A, Ko YH, et al. The anticancer agent 3-bromopyruvate: a simple but powerful molecule taken from the lab to the bedside. J Bioenerg Biomembr. 2016;48(4):349-62. https://doi.org/10.1007/s10863-016-9670-z.

33. Laussel C, Léon S. Cellular toxicity of the metabolic inhibitor 2-deoxyglucose and associated resistance mechanisms. Biochem Pharmacol. 2020;182: 114213. https://doi.org/10.1016/j.bcp.2020.114213.

34. Larrue C, Saland E, Vergez F, Serhan N, Delabesse E, Mansat-De Mas V, et al. Antileukemic activity of 2-deoxy-d-glucose through inhibition of N-linked glycosylation in acute myeloid leukemia with FLT3-ITD or c-KIT Mutations. Mol Cancer Ther. 2015;14(10):2364-73. https:/doi.org/10.1158/1535-7163.MCT-15-0163.

35. Panina SB, Pei J, Baran N, Konopleva M, Kirienko NV. Utilizing synergistic potential of mitochondria-targeting drugs for leukemia therapy. Front Oncol. 2020;10:435. https://doi.org/10.3389/fonc.2020.00435.

36. Yi M, Ban Y, Tan Y, Xiong W, Li G, Xiang B. 6-Phosphofructo-2-kinase/ fructose-2,6-biphosphatase 3 and 4: A pair of valves for fine-tuning of glucose metabolism in human cancer. Mol Metab. 2019;20:1-13. https://doi. org/10.1016/j.molmet.2018.11.013

37. Clem B, Telang S, Clem A, Yalcin A, Meier J, Simmons A, et al. Smallmolecule inhibition of 6-phosphofructo-2-kinase activity suppresses glycolytic flux and tumor growth. Mol Cancer Ther. 2008;7(1):110-20. https://doi.org/10.1158/1535-7163.MCT-07-0482.

38. Reddy MM, Fernandes MS, Deshpande A, Weisberg E, Inguilizian HV, AbdelWahab O, et al. The JAK2V617F oncogene requires expression of inducible phosphofructokinase/fructose-bisphosphatase 3 for cell growth and increased metabolic activity. Leukemia. 2012;26(3):481-9. https://doi.org/10.1 038/leu.2011.225.

39. Estey EH. Acute myeloid leukemia: 2019 update on risk-stratification and management. Am J Hematol. 2018;93(10):1267-91. https:/doi.org/10.1002/ajh.25214.

40. Moarii M, Papaemmanuil E. Classification and risk assessment in AML: integrating cytogenetics and molecular profiling. Hematology. 2017;2017(1): 37-44. https://doi.org/10.1182/asheducation-2017.1.37.
41. Papaemmanuil E, Gerstung M, Bullinger L, Gaidzik VI, Paschka P, Roberts ND, et al. Genomic classification and prognosis in acute myeloid leukemia. N Engl J Med. 2016;374(23):2209-21. https://doi.org/10.1056/NEJMoa1516192.

42. Genomic and epigenomic landscapes of adult de novo acute myeloid leukemia. New England Journal of Medicine. 2013;368(22):2059-74.

43. Ju HQ, Zhan G, Huang A, Sun Y, Wen S, Yang J, et al. ITD mutation in FLT3 tyrosine kinase promotes Warburg effect and renders therapeutic sensitivity to glycolytic inhibition. Leukemia. 2017;31(10):2143-50. https://doi.org/10.1 038/leu.2017.45

44. Chen Y, Pan Y, Guo Y, Zhao W, Ho WT, Wang J, et al. Tyrosine kinase inhibitors targeting FLT3 in the treatment of acute myeloid leukemia. Stem Cell Investig. 2017;4(6):48. https://doi.org/10.21037/sci.2017.05.04.

45. Tarver TC, Hill JE, Rahmat L, Perl AE, Bahceci E, Mori K, et al. Gilteritinib is a clinically active FLT3 inhibitor with broad activity against FLT3 kinase domain mutations. Blood Adv. 2020;4(3):514-24. https://doi.org/10.1182/ bloodadvances.2019000919.

46. Stacpoole PW. Therapeutic targeting of the pyruvate dehydrogenase complex/pyruvate dehydrogenase kinase (PDC/PDK) axis in cancer. J Natl Cancer Inst. 2017;109(11):djx071. https://academic.oup.com/jnci/article/1 09/11/djx071/3871192.

47. Cui L, Cheng Z, Liu Y, Dai Y, Pang Y, Jiao Y, et al. Overexpression of PDK2 and PDK3 reflects poor prognosis in acute myeloid leukemia. Cancer Gene Ther. 2020;27(1-2):15-21. https://doi.org/10.1038/s41417-018-0071-9.

48. Pardee TS, Anderson RG, Pladna KM, Isom S, Ghiraldeli LP, Miller LD, et al. A Phase I Study of CPI-613 in combination with high-dose cytarabine and mitoxantrone for relapsed or refractory acute myeloid leukemia. Clin Cancer Res. 2018;24(9):2060-73. https://doi.org/10.1158/1078-0432.CCR-17-2282.

49. Chifotides HT, Masarova L, Alfayez M, Daver N, Alvarado Y, Jabbour E, et al. Outcome of patients with IDH1/2-mutated post-myeloproliferative neoplasm AML in the era of IDH inhibitors. Blood Adv. 2020;4(21):5336-42. https://doi.org/10.1182/bloodadvances.2020001528.

50. Megías-Vericat JE, Ballesta-López O, Barragán E, Montesinos P. IDH1-mutated relapsed or refractory AML: current challenges and future prospects. Blood Lymphat Cancer. 2019;9:19-32. https://doi.org/10.2147/BLCTT.S177913.

51. Kingsbury JM, Shamaprasad N, Billmyre RB, Heitman J, Cardenas ME. Cancerassociated isocitrate dehydrogenase mutations induce mitochondrial DNA instability. Hum Mol Genet. 2016;25(16):3524-38. https://doi.org/10.1093/ hmg/ddw195.

52. Kickingereder P, Sahm F, Radbruch A, Wick W, Heiland S, Deimling A, et al. IDH mutation status is associated with a distinct hypoxia/angiogenesis transcriptome signature which is non-invasively predictable with rCBV imaging in human glioma. Sci Rep. 2015;5(1):16238. https://doi.org/10.1038/ srep16238.

53. Testa U, Labbaye C, Castelli G, Pelosi E. Oxidative stress and hypoxia in normal and leukemic stem cells. Exp Hematol. 2016;44(7):540-60. https:// doi.org/10.1016/..exphem.2016.04.012

54. Liu X, Gong Y. Isocitrate dehydrogenase inhibitors in acute myeloid leukemia. Biomark Res. 2019;7(1):22. https://doi.org/10.1186/s40364-019-01 73-z.

55. Kats LM, Reschke M, Taulli R, Pozdnyakova O, Burgess K, Bhargava P, et al. Proto-oncogenic role of mutant IDH2 in leukemia initiation and maintenance. Cell Stem Cell. 2014;14(3):329-41. https://doi.org/10.1016/j. stem.2013.12.016.

56. Emadi A. Exploiting AML vulnerability: glutamine dependency. Blood. 2015; 126(1 1):1269-70. https://doi.org/10.1182/blood-2015-07-659508.

57. Jewell JL, Kim YC, Russell RC, Yu FX, Park HW, Plouffe SW, et al. Metabolism. Differential regulation of mTORC1 by leucine and glutamine. Science. 2015; 347(6218):194-8. https://doi.org/10.1126/science.1259472.

58. Cluntun AA, Lukey MJ, Cerione RA, Locasale JW. Glutamine metabolism in cancer: understanding the heterogeneity. Trends Cancer. 2017;3(3):169-80 https://doi.org/10.1016/.jtrecan.2017.01.005.

59. Jacque N, Ronchetti AM, Larrue C, Meunier G, Birsen R, Willems L, et al. Targeting glutaminolysis has antileukemic activity in acute myeloid leukemia and synergizes with BCL-2 inhibition. Blood. 2015;126(11):1346-56. https://doi.org/10.1182/blood-2015-01-621870.

60. Song M, Kim SH, Im CY, Hwang HJ. Recent Development of small molecule glutaminase inhibitors. Curr Top Med Chem. 2018;18(6):432-43. https://doi. org/10.2174/1568026618666180525100830.

61. Gregory MA, Nemkov T, Park HJ, Zaberezhnyy V, Gehrke S, Adane B, et al. Targeting glutamine metabolism and redox state for leukemia therapy. Clin 
Cancer Res. 2019;25(13):4079-90. https://doi.org/10.1158/1078-0432.CCR-1 8-3223.

62. Emadi A, Jun SA, Tsukamoto T, Fathi AT, Minden MD, Dang CV. Inhibition of glutaminase selectively suppresses the growth of primary acute myeloid leukemia cells with IDH mutations. Exp Hematol. 2014;42(4):247-51. https:// doi.org/10.1016/j.exphem.2013.12.001.

63. Gregory MA, D'Alessandro A, Alvarez-Calderon F, Kim J, Nemkov T, Adane B, et al. ATM/G6PD-driven redox metabolism promotes FLT3 inhibitor resistance in acute myeloid leukemia. Proc Natl Acad Sci U S A. 2016; 113(43):E6669-E78. https://doi.org/10.1073/pnas.1603876113.

64. Gallipoli P, Giotopoulos G, Tzelepis K, Costa ASH, Vohra S, Medina-Perez P, et al. Glutaminolysis is a metabolic dependency in FLT3. Blood. 2018; 131(15):1639-53. https://doi.org/10.1182/blood-2017-12-820035.

65. Skrtić M, Sriskanthadevan S, Jhas B, Gebbia M, Wang X, Wang Z, et al. Inhibition of mitochondrial translation as a therapeutic strategy for human acute myeloid leukemia. Cancer Cell. 2011;20(5):674-88. https://doi.org/10.1 016/j.ccr.2011.10.015.

66. Sriskanthadevan S, Jeyaraju DV, Chung TE, Prabha S, Xu W, Skrtic M, et al. AML cells have low spare reserve capacity in their respiratory chain that renders them susceptible to oxidative metabolic stress. Blood. 2015;125(13): 2120-30. https://doi.org/10.1182/blood-2014-08-594408.

67. Panina SB, Baran N, Brasil da Costa FH, Konopleva M, Kirienko NV. A mechanism for increased sensitivity of acute myeloid leukemia to mitotoxic drugs. Cell Death Dis. 2019;10(8):617.

68. Farge T, Saland E, de Toni F, Aroua N, Hosseini M, Perry R, et al. Chemotherapy-resistant human acute myeloid leukemia cells are not enriched for leukemic stem cells but require oxidative metabolism. Cancer Discov. 2017;7(7):716-35. https://doi.org/10.1158/2159-8290.CD-16-0441.

69. Basak NP, Banerjee S. Mitochondrial dependency in progression of acute myeloid leukemia. Mitochondrion. 2015;21:41-8. https://doi.org/10.1016/j. mito.2015.01.006.

70. Schimmer AD, Skrtić M. Therapeutic potential of mitochondrial translation inhibition for treatment of acute myeloid leukemia. Expert Rev Hematol. 2012;5(2):117-9. https://doi.org/10.1586/ehm.12.8.

71. Kang MG, Kim YN, Lee JH, Szardenings M, Baek HJ, Kook H, et al. Clinicopathological implications of mitochondrial genome alterations in pediatric acute myeloid leukemia. Ann Lab Med. 2016;36(2):101-10. https:// doi.org/10.3343/alm.2016.36.2.101.

72. Lagadinou ED, Sach A, Callahan K, Rossi RM, Neering SJ, Minhajuddin M, et al. BCL-2 inhibition targets oxidative phosphorylation and selectively eradicates quiescent human leukemia stem cells. Cell Stem Cell. 2013;12(3): 329-41. https://doi.org/10.1016/j.stem.2012.12.013.

73. Reed GA, Schiller GJ, Kambhampati S, Tallman MS, Douer D, Minden MD, et al. A phase 1 study of intravenous infusions of tigecycline in patients with acute myeloid leukemia. Cancer Med. 2016;5(11):3031-40. https://doi. org/10.1002/cam4.845

74. Moschoi R, Imbert V, Nebout M, Chiche J, Mary D, Prebet T, et al. Protective mitochondrial transfer from bone marrow stromal cells to acute myeloid leukemic cells during chemotherapy. Blood. 2016;128(2):253-64. https://doi. org/10.1182/blood-2015-07-655860.

75. Forte D, García-Fernández M, Sánchez-Aguilera A, Stavropoulou V, Fielding C, Martín-Pérez D, et al. Bone Marrow Mesenchymal stem cells support acute myeloid leukemia bioenergetics and enhance antioxidant defense and escape from chemotherapy. Cell Metab. 2020;32(5):829-43.e9.

76. Wu S, Akhtari M, Alachkar H. Characterization of mutations in the mitochondrial encoded electron transport chain complexes in acute myeloid leukemia. Sci Rep. 2018;8(1):13301. https://doi.org/10.1038/s41598-018-31489-0.

77. Stuani L, Sabatier M, Sarry JE. Exploiting metabolic vulnerabilities for personalized therapy in acute myeloid leukemia. BMC Biol. 2019;17(1):57. https://doi.org/10.1186/s12915-019-0670-4.

78. Biondani G, Peyron JF. Metformin, an anti-diabetic drug to target leukemia. Front Endocrinol (Lausanne). 2018;9:446.

79. Scotland S, Saland E, Skuli N, de Toni F, Boutzen H, Micklow E, et al. Mitochondrial energetic and AKT status mediate metabolic effects and apoptosis of metformin in human leukemic cells. Leukemia. 2013;27(11): 2129-38. https://doi.org/10.1038/leu.2013.107.

80. Renner K, Seilbeck A, Kauer N, Ugele I, Siska PJ, Brummer C, et al. Combined metabolic targeting with metformin and the NSAIDs diflunisal and diclofenac induces apoptosis in acute myeloid leukemia cells. Front Pharmacol. 2018:9:1258. https://doi.org/10.3389/fphar.2018.01258.
81. Molina JR, Sun Y, Protopopova M, Gera S, Bandi M, Bristow C, et al. An inhibitor of oxidative phosphorylation exploits cancer vulnerability. Nat Med. 2018;24(7):1036-46. https://doi.org/10.1038/s41591-018-0052-4.

82. Liu F, Kalpage HA, Wang D, Edwards H, Hüttemann M, Ma J, et al. Cotargeting of mitochondrial complex I and Bcl-2 shows antileukemic activity against acute myeloid leukemia cells reliant on oxidative phosphorylation. Cancers (Basel). 2020;12(9):2400.

83. Matsunaga T, Kudo J, Takahashi K, Dohmen K, Hayashida K, Okamura S, et al. Rotenone, a mitochondrial NADH dehydrogenase inhibitor, induces cell surface expression of CD13 and CD38 and apoptosis in HL-60 cells. Leuk Lymphoma. 1996;20(5-6):487-94. https://doi.org/10.3109/104281 99609052434

84. Heinz S, Freyberger A, Lawrenz B, Schladt L, Schmuck G, EllingerZiegelbauer $\mathrm{H}$. Mechanistic investigations of the mitochondrial complex I inhibitor rotenone in the context of pharmacological and safety evaluation. Sci Rep. 2017;7(1):45465. https://doi.org/10.1038/srep45465.

85. Baccelli I, Gareau Y, Lehnertz B, Gingras S, Spinella JF, Corneau S, et al, Mubritinib targets the electron transport chain complex I and reveals the landscape of OXPHOS dependency in acute myeloid leukemia. Cancer Cell. 2019;36(1):84-99.e8.

86. Pollyea DA, Stevens BM, Jones $C L$, Winters A, Pei S, Minhajuddin M, et al. Venetoclax with azacitidine disrupts energy metabolism and targets leukemia stem cells in patients with acute myeloid leukemia. Nat Med. 2018;24(12):1859-66. https://doi.org/10.1038/s41591-018-0233-1.

87. Akers LJ, Fang W, Levy AG, Franklin AR, Huang P, Zweidler-McKay PA. Targeting glycolysis in leukemia: a novel inhibitor 3-BrOP in combination with rapamycin. Leuk Res. 2011;35(6):814-20. https://doi.org/10.1016/j. leukres.2010.12.028.

88. Levy AG, Zage PE, Akers $L$, Ghisoli ML, Chen Z, Fang W, et al. The combination of the novel glycolysis inhibitor 3-BrOP and rapamycin is effective against neuroblastoma. Invest New Drugs. 2012;30(1):191-9. https://doi.org/10.1007/s10637-010-9551-y.

89. Alvarez-Calderon F, Gregory MA, Pham-Danis C, DeRyckere D, Stevens BM, Zaberezhnyy $\mathrm{V}$, et al. Tyrosine kinase inhibition in leukemia induces an altered metabolic state sensitive to mitochondrial perturbations. Clin Cancer Res. 2015;21(6):1360-72. https://doi.org/10.1158/1078-0432.CCR-14-2146.

90. Cole A, Wang Z, Coyaud E, Voisin V, Gronda M, Jitkova Y, et al. Inhibition of the mitochondrial protease ClpP as a therapeutic strategy for human acute myeloid leukemia. Cancer Cell. 2015;27(6):864-76. https://doi.org/10.1016/j. ccell.2015.05.004.

91. Haynes CM, Yang Y, Blais SP, Neubert TA, Ron D. The matrix peptide exporter HAF-1 signals a mitochondrial UPR by activating the transcription factor ZC376.7 in C. elegans. Mol Cell. 2010;37(4):529-40. https://doi.org/10.1 016/j.molcel.2010.01.015.

92. Ray PD, Huang BW, Tsuji Y. Reactive oxygen species (ROS) homeostasis and redox regulation in cellular signaling. Cell Signal. 2012;24(5):981-90. https:// doi.org/10.1016/j.cellsig.2012.01.008

93. Sillar JR, Germon ZP, Deluliis GN, Dun MD. The role of reactive oxygen species in acute myeloid leukaemia. Int J Mol Sci. 2019;20(23):6003.

94. Guha M, Avadhani NG. Mitochondrial retrograde signaling at the crossroads of tumor bioenergetics, genetics and epigenetics. Mitochondrion. 2013; 13(6):577-91. https://doi.org/10.1016/j.mito.2013.08.007.

95. Jayavelu AK, Moloney JN, Böhmer FD, Cotter TG. NOX-driven ROS formation in cell transformation of FLT3-ITD-positive AML. Exp Hematol. 2016;44(12): 1113-22. https://doi.org/10.1016/j.exphem.2016.08.008.

96. Marlein CR, Zaitseva L, Piddock RE, Robinson SD, Edwards DR, Shafat MS, et al. NADPH oxidase-2 derived superoxide drives mitochondrial transfer from bone marrow stromal cells to leukemic blasts. Blood. 2017;130(14): 1649-60. https://doi.org/10.1182/blood-2017-03-772939.

97. Ludin A, Gur-Cohen S, Golan K, Kaufmann KB, Itkin T, Medaglia C, et al. Reactive oxygen species regulate hematopoietic stem cell self-renewal, migration and development, as well as their bone marrow microenvironment. Antioxid Redox Signal. 2014;21 (11):1605-19. https://doi.org/10.1089/ars.2014.5941.

98. Mailloux RJ, McBride SL, Harper ME. Unearthing the secrets of mitochondrial ROS and glutathione in bioenergetics. Trends Biochem Sci. 2013;38(12):592602. https://doi.org/10.1016/j.tibs.2013.09.001.

99. Brookes PS. Mitochondrial $\mathrm{H}(+)$ leak and ROS generation: an odd couple. Free Radic Biol Med. 2005;38(1):12-23. https://doi.org/10.1016/jffreera dbiomed.2004.10.016. 
100. Vélez J, Hail N, Konopleva M, Zeng Z, Kojima K, Samudio I, et al. Mitochondrial uncoupling and the reprograming of intermediary metabolism in leukemia cells. Front Oncol. 2013;3:67.

101. Prieto-Bermejo R, Romo-González M, Pérez-Fernández A, ljurko C, Hernández-Hernández Á. Reactive oxygen species in haematopoiesis: leukaemic cells take a walk on the wild side. J Exp Clin Cancer Res. 2018; 37(1):125. https://doi.org/10.1186/s13046-018-0797-0.

102. Petruccelli LA, Dupere-Richer D, Pettersson F, Retrouvey H, Skoulikas S, Miller WH Jr. Vorinostat induces reactive oxygen species and DNA damage in acute myeloid leukemia cells. Plos One. 2011;6(6):e20987. https://doi.org/1 0.1371/journal.pone.0020987.

103. Perillo B, Di Donato M, Pezone A, Di Zazzo E, Giovannelli P, Galasso G, et al. ROS in cancer therapy: the bright side of the moon. Exp Mol Med. 2020; 52(2):192-203. https://doi.org/10.1038/s12276-020-0384-2.

104. Ichikawa Y, Ghanefar M, Bayeva M, Wu R, Khechaduri A, Naga Prasad SV, et al. Cardiotoxicity of doxorubicin is mediated through mitochondrial iron accumulation. J Clin Invest. 2014;124(2):617-30. https://doi.org/10.1172/JCl72 931.

105. Hu Y, Lu W, Chen G, Zhang H, Jia Y, Wei Y, et al. Overcoming resistance to histone deacetylase inhibitors in human leukemia with the redox modulating compound $\beta$-phenylethyl isothiocyanate. Blood. 2010;116(15): 2732-41. https://doi.org/10.1182/blood-2009-11-256354.

106. Zhu HH, Hu J, Lo-Coco F, Jin J. The simpler, the better: oral arsenic for acute promyelocytic leukemia. Blood. 2019;134(7):597-605. https://doi.org/10.11 82/blood.2019000760.

107. Kumana CR, Mak R, Kwong YL, Gill H. Resurrection of oral arsenic trioxide for treating acute promyelocytic leukaemia: a historical account from bedside to bench to bedside. Front Oncol. 2020;10:1294. https://doi.org/10.3389/ fonc.2020.01294.

108. Adès L, Thomas X, Bresler AG, Raffoux E, Spertini O, Vey N, et al. Arsenic trioxide is required in the treatment of newly diagnosed acute promyelocytic leukemia. Analysis of a randomized trial (APL 2006) by the French Belgian Swiss APL group. Haematologica. 2018;103(12):2033-9. https://doi.org/10.3324/haematol.2018.198614.

109. Kumar S, Yedjou CG, Tchounwou PB. Arsenic trioxide induces oxidative stress, DNA damage, and mitochondrial pathway of apoptosis in human leukemia (HL-60) cells. J Exp Clin Cancer Res. 2014;33(1):42. https://doi.org/1 0.1186/1756-9966-33-42.

110. Pelicano H, Feng L, Zhou Y, Carew JS, Hileman EO, Plunkett W, et al. Inhibition of mitochondrial respiration: a novel strategy to enhance druginduced apoptosis in human leukemia cells by a reactive oxygen speciesmediated mechanism. J Biol Chem. 2003;278(39):37832-9. https://doi.org/1 0.1074/jbc.M301546200.

111. Coe E, Schimmer AD. Catalase activity and arsenic sensitivity in acute leukemia. Leuk Lymphoma. 2008;49(10):1976-81. https://doi.org/10.1080/1 0428190802353617.

112. Noguera NI, Pelosi E, Angelini DF, Piredda ML, Guerrera G, Piras E, et al. High-dose ascorbate and arsenic trioxide selectively kill acute myeloid leukemia and acute promyelocytic leukemia blasts in vitro. Oncotarget. 2017;8(20):32550-65. https://doi.org/10.18632/oncotarget.15925.

113. Aldoss I, Mark L, Vrona J, Ramezani L, Weitz I, Mohrbacher AM, et al. Adding ascorbic acid to arsenic trioxide produces limited benefit in patients with acute myeloid leukemia excluding acute promyelocytic leukemia. Ann Hematol. 2014;93(11):1839-43. https://doi.org/10.1007/s00277-014-2124-y.

114. Siveen KS, Uddin S, Mohammad RM. Targeting acute myeloid leukemia stem cell signaling by natural products. Mol Cancer. 2017;16(1):13. https:// doi.org/10.1186/s12943-016-0571-x.

115. D'Anneo A, Carlisi D, Lauricella M, Puleio R, Martinez R, Di Bella S, et al. Parthenolide generates reactive oxygen species and autophagy in MDAMB231 cells. A soluble parthenolide analogue inhibits tumour growth and metastasis in a xenograft model of breast cancer. Cell Death Dis. 2013;4: e891.

116. Pei S, Minhajuddin M, D’Alessandro A, Nemkov T, Stevens BM, Adane B, et al. Rational design of a parthenolide-based drug regimen that selectively eradicates acute myelogenous leukemia stem cells. J Biol Chem. 2016; 291(42):21984-2000. https://doi.org/10.1074/jbc.M116.750653.

117. Neuzil J, Wang XF, Dong LF, Low P, Ralph SJ. Molecular mechanism of 'mitocan'-induced apoptosis in cancer cells epitomizes the multiple roles of reactive oxygen species and Bcl-2 family proteins. FEBS Lett. 2006;580(22): 5125-9. https://doi.org/10.1016/j.febslet.2006.05.072.
118. Kalainayakan SP, Ghosh P, Dey S, Fitzgerald KE, Sohoni S, Konduri PC, et al. Cyclopamine tartrate, a modulator of hedgehog signaling and mitochondria respiration, effectively arrests lung tumor growth and progression. Sci Rep. 2019;9(1):1405. https://doi.org/10.1038/s41598-018-38345-1.

119. Heasman SA, Zaitseva L, Bowles KM, Rushworth SA, Macewan DJ. Protection of acute myeloid leukaemia cells from apoptosis induced by front-line chemotherapeutics is mediated by haem oxygenase-1. Oncotarget. 2011; 2(9):658-68. https://doi.org/10.18632/oncotarget.321.

120. Ryter SW, Kim HP, Hoetzel A, Park JW, Nakahira K, Wang X, et al. Mechanisms of cell death in oxidative stress. Antioxid Redox Signal. 2007; 9(1):49-89. https://doi.org/10.1089/ars.2007.9.49.

121. Redza-Dutordoir M, Averill-Bates DA. Activation of apoptosis signalling pathways by reactive oxygen species. Biochim Biophys Acta. 2016;1863(12): 2977-92. https://doi.org/10.1016/j.bbamcr.2016.09.012.

122. Castelli G, Pelosi E, Testa U. Emerging Therapies for acute myelogenus leukemia patients targeting apoptosis and mitochondrial metabolism. Cancers (Basel). 2019;11(2):260.

123. Yu Y, Xie Y, Cao L, Yang L, Yang M, Lotze MT, et al. The ferroptosis inducer erastin enhances sensitivity of acute myeloid leukemia cells to chemotherapeutic agents. Mol Cell Oncol. 2015;2(4):e1054549. https://doi. org/10.1080/23723556.2015.1054549.

124. Li J, Cao F, Yin HL, Huang ZJ, Lin ZT, Mao N, et al. Ferroptosis: past, present and future. Cell Death Dis. 2020;11(2):88. https://doi.org/10.1038/s41419-02 0-2298-2.

125. Guilloton F, Jean C, de Thonel A, Laurent G, Quillet-Mary A. Granzyme B induction signalling pathway in acute myeloid leukemia cell lines stimulated by tumor necrosis factor alpha and Fas ligand. Cell Signal. 2007; 19(6):1132-40. https://doi.org/10.1016/j.cellsig.2006.12.005.

126. Sallmyr A, Fan J, Rassool FV. Genomic instability in myeloid malignancies: increased reactive oxygen species (ROS), DNA double strand breaks (DSBS) and error-prone repair. Cancer Lett. 2008;270(1):1-9. https://doi.org/10.1016/ j.canlet.2008.03.036.

127. Bradbury DA, Zhu YM, Russell NH. Bcl-2 expression in acute myeloblastic leukaemia: relationship with autonomous growth and CD34 antigen expression. Leuk Lymphoma. 1997;24(3-4):221-8. https://doi.org/10.3109/1 0428199709039010.

128. McBride A, Houtmann S, Wilde L, Vigil C, Eischen CM, Kasner M, et al. The role of inhibition of apoptosis in acute leukemias and myelodysplastic syndrome. Front Oncol. 2019;9:192. https://doi.org/10.3389/fonc.2019.00192.

129. Ryan JA, Brunelle JK, Letai A. Heightened mitochondrial priming is the basis for apoptotic hypersensitivity of CD4+ CD8+ thymocytes. Proc Natl Acad Sci U S A. 2010;107(29):12895-900. https://doi.org/10.1073/pnas.0914878107.

130. Kalkavan $H$, Green DR. MOMP, cell suicide as a BCL-2 family business. Cell Death Differ. 2018;25(1):46-55. https://doi.org/10.1038/cdd.2017.179.

131. Bohl SR, Bullinger $L$, Rücker FG. New targeted agents in acute myeloid leukemia: new hope on the rise. Int J Mol Sci. 2019;20(8):1983.

132. Kale J, Osterlund EJ, Andrews DW. BCL-2 family proteins: changing partners in the dance towards death. Cell Death Differ. 2018;25(1):65-80. https://doi. org/10.1038/cdd.2017.186.

133. Jonas BA, Pollyea DA. How we use venetoclax with hypomethylating agents for the treatment of newly diagnosed patients with acute myeloid leukemia. Leukemia. 2019;33(12):2795-804. https://doi.org/10.1038/s41375019-0612-8.

134. Cang S, Iragavarapu C, Savooji J, Song Y, Liu D. ABT-199 (venetoclax) and BCL-2 inhibitors in clinical development. J Hematol Oncol. 2015;8(1):129. https://doi.org/10.1186/s13045-015-0224-3.

135. Montero J, Letai A. Why do BCL-2 inhibitors work and where should we use them in the clinic? Cell Death Differ. 2018;25(1):56-64. https://doi.org/10.103 8/cdd.2017.183.

136. DiNardo CD, Pratz K, Pullarkat V, Jonas BA, Arellano M, Becker PS, et al. Venetoclax combined with decitabine or azacitidine in treatment-naive, elderly patients with acute myeloid leukemia. Blood. 2019;133(1):7-17. https://doi.org/10.1182/blood-2018-08-868752

137. Deeks ED. Venetoclax: First Global Approval. Drugs. 2016;76(9):979-87. https://doi.org/10.1007/s40265-016-0596-x.

138. Konopleva M, Pollyea DA, Potluri J, Chyla B, Hogdal L, Busman T, et al. Efficacy and Biological correlates of response in a phase II study of venetoclax monotherapy in patients with acute myelogenous leukemia. Cancer Discov. 2016;6(10):1106-17. https://doi.org/10.1158/2159-8290.CD-16-0313.

139. Samra B, Konopleva M, Isidori A, Daver N, DiNardo C. Venetoclax-based combinations in acute myeloid leukemia: current evidence and future 
directions. Front Oncol. 2020;10:562558. https://doi.org/10.3389/fonc.2020. 562558.

140. Luedtke DA, Niu X, Pan Y, Zhao J, Liu S, Edwards H, et al. Inhibition of Mcl-1 enhances cell death induced by the BCl-2-selective inhibitor ABT-199 in acute myeloid leukemia cells. Signal Transduct Target Ther. 2017;2(1):17012. https://doi.org/10.1038/sigtrans.2017.12.

141. Bolomsky A, Vogler M, Köse MC, Heckman CA, Ehx G, Ludwig H, et al. MCL1 inhibitors, fast-lane development of a new class of anti-cancer agents. J Hematol Oncol. 2020;13(1):173. https://doi.org/10.1186/s13045-020-01007-9.

142. Sharon D, Cathelin S, Mirali S, Di Trani JM, Yanofsky DJ, Keon KA, et al. Inhibition of mitochondrial translation overcomes venetoclax resistance in AML through activation of the integrated stress response. Sci Transl Med. 2019;11(516):eaax2863. https://pubmed.ncbi.nlm.nih.gov/31666400/.

143. Rehm M, Huber HJ, Hellwig CT, Anguissola S, Dussmann H, Prehn JH. Dynamics of outer mitochondrial membrane permeabilization during apoptosis. Cell Death Differ. 2009;16(4):613-23. https://doi.org/10.1038/cdd.2 008.187 .

144. Bhola PD, Mattheyses AL, Simon SM. Spatial and temporal dynamics of mitochondrial membrane permeability waves during apoptosis. Biophys J. 2009;97(8):2222-31. https://doi.org/10.1016/j.bpj.2009.07.056.

145. Ni Chonghaile T, Sarosiek KA, Vo TT, Ryan JA, Tammareddi A, VeG M, et al. Pretreatment mitochondrial priming correlates with clinical response to cytotoxic chemotherapy. Science. 2011;334(6059):1129-33. https://doi.org/1 $0.1126 /$ science. 1206727.

146. Youle RJ, Narendra DP. Mechanisms of mitophagy. Nat Rev Mol Cell Biol. 2011;12(1):9-14. https://doi.org/10.1038/nrm3028.

147. Wang N, Zhu P, Huang R, Wang C, Sun L, Lan B, et al. PINK1: The guard of mitochondria. Life Sci. 2020;259:118247. https://doi.org/10.1016/j.lfs.2020.11 8247.

148. Kim Y, Park J, Kim S, Song S, Kwon SK, Lee SH, et al. PINK1 controls mitochondrial localization of Parkin through direct phosphorylation. Biochem Biophys Res Commun. 2008;377(3):975-80. https://doi.org/10.1016/ j.bbrc.2008.10.104

149. Okatsu K, Oka T, Iguchi M, Imamura K, Kosako H, Tani N, et al. PINK1 autophosphorylation upon membrane potential dissipation is essential for Parkin recruitment to damaged mitochondria. Nat Commun. 2012;3(1):1016. https://doi.org/10.1038/ncomms2016.

150. Shiba-Fukushima K, Imai Y, Yoshida S, Ishihama Y, Kanao T, Sato S, et al. PINK1-mediated phosphorylation of the Parkin ubiquitin-like domain primes mitochondrial translocation of Parkin and regulates mitophagy. Sci Rep. 2012;2(1):1002. https://doi.org/10.1038/srep01002.

151. Bialik S, Dasari SK, Kimchi A. Autophagy-dependent cell death - where, how and why a cell eats itself to death. J Cell Sci. 2018;131(18):jcs215152. https:// pubmed.ncbi.nlm.nih.gov/30237248/.

152. Rodrigo R, Mendis N, Ibrahim M, Ma C, Kreinin E, Roma A, et al. Knockdown of BNIP3L or SQSTM1 alters cellular response to mitochondria target drugs. Autophagy. 2019;15(5):900-7. https://doi.org/10.1080/15548627.2018.1 558002

153. Nguyen TD, Shaid S, Vakhrusheva O, Koschade SE, Klann K, Thölken M, et al. Loss of the selective autophagy receptor p62 impairs murine myeloid leukemia progression and mitophagy. Blood. 2019;133(2):168-79. https://doi. org/10.1182/blood-2018-02-833475.

154. Pei S, Minhajuddin M, Adane B, Khan N, Stevens BM, Mack SC, et al. AMPK FIS1-mediated mitophagy is required for self-renewal of human AML stem cells. Cell Stem Cell. 2018;23(1):86-100.e6.

155. Fay HRS, Dykstra KM, Johnson M, Cronin TL, Lutgen-Dunckley L, Martens BL, et al. Mitophagy plays a key role in the anti-leukemic activity of autophagy inhibitors under hypoxia in acute myeloid leukemia. Blood. 2019;134(Suppl. 1):1278. https://doi.org/10.1182/blood-2019-127024.

156. Basit F, van Oppen LM, Schöckel L, Bossenbroek HM, van Emst-de Vries SE, Hermeling JC, et al. Mitochondrial complex I inhibition triggers a mitophagy-dependent ROS increase leading to necroptosis and ferroptosis in melanoma cells. Cell Death Dis. 2017;8(3):e2716. https://doi.org/10.1038/ coddis.2017.133.

157. Wang WJ, Wang Y, Chen HZ, Xing YZ, Li FW, Zhang Q, et al. Orphan nuclear receptor TR3 acts in autophagic cell death via mitochondrial signaling pathway. Nat Chem Biol. 2014;10(2):133-40. https://doi.org/10.1038/ nchembio. 1406

158. Watson AS, Riffelmacher T, Stranks A, Williams O, De Boer J, Cain K, et al. Autophagy limits proliferation and glycolytic metabolism in acute myeloid leukemia. Cell Death Discov. 2015;1(1). https:/doi.org/10.1038/cddiscovery.2015.8.
159. Kim EH, Sohn S, Kwon HJ, Kim SU, Kim MJ, Lee SJ, et al. Sodium selenite induces superoxide-mediated mitochondrial damage and subsequent autophagic cell death in malignant glioma cells. Cancer Res. 2007;67(13): 6314-24. https://doi.org/10.1158/0008-5472.CAN-06-4217.

160. Qu X, Yu J, Bhagat G, Furuya N, Hibshoosh H, Troxel A, et al. Promotion of tumorigenesis by heterozygous disruption of the beclin 1 autophagy gene. J Clin Invest. 2003;112(12):1809-20. https://doi.org/10.1172/JCI20039.

161. Fimia GM, Stoykova A, Romagnoli A, Giunta L, Di Bartolomeo S, Nardacci R, et al. Ambra1 regulates autophagy and development of the nervous system. Nature. 2007;447(7148):1121-5. https://doi.org/10.1038/nature05925.

162. Mortensen M, Soilleux EJ, Djordjevic G, Tripp R, Lutteropp M, Sadighi-Akha $E$, et al. The autophagy protein Atg7 is essential for hematopoietic stem cell maintenance. J Exp Med. 2011;208(3):455-67. https://doi.org/10.1084/jem.2 0101145.

163. Dany M, Gencer S, Nganga R, Thomas RJ, Oleinik N, Baron KD, et al. Targeting FLT3-ITD signaling mediates ceramide-dependent mitophagy and attenuates drug resistance in AML. Blood. 2016;128(15):1944-58. https://doi. org/10.1182/blood-2016-04-708750.

164. Sentelle RD, Senkal CE, Jiang W, Ponnusamy S, Gencer S, Selvam SP, et al. Ceramide targets autophagosomes to mitochondria and induces lethal mitophagy. Nat Chem Biol. 2012;8(10):831-8. https://doi.org/10.1038/ nchembio.1059.

165. Butturini A, Santucci MA, Gale RP, Perocco P, Tura S. GM-CSF incubation prior to treatment with cytarabine or doxorubicin enhances drug activity against AML cells in vitro: a model for leukemia chemotherapy. Leuk Res. 1990;14(9):743-9. https://doi.org/10.1016/0145-2126(90)90066-I.

166. Wu D, Duan C, Chen L, Chen S. Efficacy and safety of different doses of cytarabine in consolidation therapy for adult acute myeloid leukemia patients: a network meta-analysis. Sci Rep. 2017;7(1):9509. https://doi.org/1 0.1038/s41598-017-10368-0.

167. Harousseau JL, Rigal-Huguet F, Hurteloup P, Guy H, Milpied N, Pris J. Treatment of acute myeloid leukemia in elderly patients with oral idarubicin as a single agent. Eur J Haematol. 1989;42(2):182-5. https://doi.org/10.1111/ j.1600-0609.1989.tb01208.x.

168. Bailly JD, Skladanowski A, Bettaieb A, Mansat V, Larsen AK, Laurent G. Natural resistance of acute myeloid leukemia cell lines to mitoxantrone is associated with lack of apoptosis. Leukemia. 1997;11(9):1523-32. https://doi. org/10.1038/sj.leu.2400762.

169. Paciucci PA, Cuttner J, Holland JF. Mitoxantrone as a single agent and in combination chemotherapy in patients with refractory acute leukemia. Semin Oncol. 1984;11(3 Suppl 1):36-40.

170. Wang Y, Zhou R, Liliemark J, Gruber A, Lindemalm S, Albertioni F, et al. In vitro topo II--DNA complex accumulation and cytotoxicity of etoposide in leukaemic cells from patients with acute myelogenous and chronic lymphocytic leukaemia. Leuk Res. 2001;25(2):133-40. https://doi.org/10.1016/ S0145-2126(00)00103-X.

171. Osby E, Liliemark E, Björkholm M, Liliemark J. Oral etoposide in patients with hematological malignancies: a clinical and pharmacokinetic study. Med Oncol. 2001;18(4):269-75. https://doi.org/10.1385/MO:18:4:269.

172. Liyanage SU, Hurren R, Voisin V, Bridon G, Wang X, Xu C, et al. Leveraging increased cytoplasmic nucleoside kinase activity to target mtDNA and oxidative phosphorylation in AML. Blood. 2017;129(19):2657-66. https://doi. org/10.1182/blood-2016-10-741207.

173. Yehudai D, Liyanage SU, Hurren R, Rizoska B, Albertella M, Gronda M, et al. The thymidine dideoxynucleoside analog, alovudine, inhibits the mitochondrial DNA polymerase $\gamma$, impairs oxidative phosphorylation and promotes monocytic differentiation in acute myeloid leukemia. Haematologica. 2019;104(5):963-72. https://doi.org/10.3324/haematol.2018.1 95172.

174. Yeung M, Hurren R, Nemr C, Wang X, Hershenfeld S, Gronda M, et al. Mitochondrial DNA damage by bleomycin induces AML cell death. Apoptosis. 2015;20(6):811-20. https://doi.org/10.1007/s10495-015-1119-z.

175. Konopleva M, Contractor R, Tsao T, Samudio I, Ruvolo PP, Kitada S, et al. Mechanisms of apoptosis sensitivity and resistance to the $\mathrm{BH} 3$ mimetic ABT737 in acute myeloid leukemia. Cancer Cell. 2006;10(5):375-88. https://doi. org/10.1016/.ccr.2006.10.006.

176. Souers AJ, Leverson JD, Boghaert ER, Ackler SL, Catron ND, Chen J, et al. ABT-199, a potent and selective BCL-2 inhibitor, achieves antitumor activity while sparing platelets. Nat Med. 2013;19(2):202-8. https://doi.org/10.1038/ nm.3048. 
177. Pan R, Hogdal LJ, Benito JM, Bucci D, Han L, Borthakur G, et al. Selective BCL-2 inhibition by ABT-199 causes on-target cell death in acute myeloid leukemia. Cancer Discov. 2014;4(3):362-75. https://doi.org/10.1158/2159-82 90.CD-13-0609.

178. Konopleva M, Watt J, Contractor R, Tsao T, Harris D, Estrov Z, et al. Mechanisms of antileukemic activity of the novel $\mathrm{BCl}-2$ homology domain-3 mimetic GX15-070 (obatoclax). Cancer Res. 2008;68(9):3413-20. https://doi. org/10.1158/0008-5472.CAN-07-1919.

179. Schimmer AD, Raza A, Carter TH, Claxton D, Erba H, DeAngelo DJ, et al. A multicenter phase $1 / \|$ study of obatoclax mesylate administered as a 3- or 24-hour infusion in older patients with previously untreated acute myeloid leukemia. Plos One. 2014;9(10):e108694. https://doi.org/10.1371/journal.pone. 0108694.

180. Schimmer AD, O'Brien S, Kantarjian H, Brandwein J, Cheson BD, Minden MD, et al. A phase I study of the pan bcl-2 family inhibitor obatoclax mesylate in patients with advanced hematologic malignancies. Clin Cancer Res. 2008; 14(24):8295-301. https://doi.org/10.1158/1078-0432.CCR-08-0999.

181. Kotschy A, Szlavik Z, Murray J, Davidson J, Maragno AL, Le Toumelin-Braizat $\mathrm{G}$, et al. The MCL1 inhibitor $\mathbf{S 6 3 8 4 5}$ is tolerable and effective in diverse cancer models. Nature. 2016;538(7626):477-82. https://doi.org/10.1038/na ture19830.

182. Wang Q, Hao S. A-1210477, a selective MCL-1 inhibitor, overcomes ABT-737 resistance in AML. Oncol Lett. 2019;18(5):5481-9. https://doi.org/10.3892/ol.2 019.10891.

183. Tron AE, Belmonte MA, Adam A, Aquila BM, Boise LH, Chiarparin E, et al. Discovery of MCl-1-specific inhibitor AZD5991 and preclinical activity in multiple myeloma and acute myeloid leukemia. Nat Commun. 2018;9(1): 5341. https://doi.org/10.1038/s41467-018-07551-w.

184. dos Santos GA, Abreu e Lima RS, Pestana CR, Lima AS, Scheucher PS, Thomé $\mathrm{CH}$, et al. (+)a-Tocopheryl succinate inhibits the mitochondrial respiratory chain complex I and is as effective as arsenic trioxide or ATRA against acute promyelocytic leukemia in vivo. Leukemia. 2012;26(3):451-60. https://doi.org/10.1038/leu.2011.216.

185. Yamamoto S, Tamai H, Ishisaka R, Kanno T, Arita K, Kobuchi H, et al. Mechanism of alpha-tocopheryl succinate-induced apoptosis of promyelocytic leukemia cells. Free Radic Res. 2000;33(4):407-18. https://doi. org/10.1080/10715760000300941

186. Calviño E, Estañ MC, Sánchez-Martín C, Brea R, de Blas E. Boyano-Adánez $\mathrm{MeC}$, et al. Regulation of death induction and chemosensitizing action of 3bromopyruvate in myeloid leukemia cells: energy depletion, oxidative stress, and protein kinase activity modulation. J Pharmacol Exp Ther. 2014;348(2): 324-35. https://doi.org/10.1124/jpet.113.206714.

187. Chen Z, Zhang H, Lu W, Huang P. Role of mitochondria-associated hexokinase II in cancer cell death induced by 3-bromopyruvate. Biochim Biophys Acta. 2009;1787(5):553-60. https://doi.org/10.1016/j.bbabio.2009.03. 003.

188. Pardee TS, Lee K, Luddy J, Maturo C, Rodriguez R, Isom S, et al. A phase I study of the first-in-class antimitochondrial metabolism agent, CPI-613, in patients with advanced hematologic malignancies. Clin Cancer Res. 2014; 20(20):5255-64. https://doi.org/10.1158/1078-0432.CCR-14-1019.

189. Qin L, Tian Y, Yu Z, Shi D, Wang J, Zhang C, et al. Targeting PDK1 with dichloroacetophenone to inhibit acute myeloid leukemia (AML) cell growth. Oncotarget. 2016;7(2):1395-407. https://doi.org/10.18632/oncotarget.6366.

190. Yen K, Travins J, Wang F, David MD, Artin E, Straley K, et al. AG-221, a firstin-class therapy targeting acute myeloid leukemia harboring oncogenic IDH2 mutations. Cancer Discov. 2017;7(5):478-93. https://doi.org/10.1158/21 59-8290.CD-16-1034.

191. Stein EM, DiNardo CD, Pollyea DA, Fathi AT, Roboz GJ, Altman JK, et al. Enasidenib in mutant. Blood. 2017;130(6):722-31. https://doi.org/10.1182/ blood-2017-04-779405.

192. Matre P, Velez J, Jacamo R, Qi Y, Su X, Cai T, et al. Inhibiting glutaminase in acute myeloid leukemia: metabolic dependency of selected AML subtypes. Oncotarget. 2016;7(48):79722-35. https://doi.org/10.18632/oncotarget.12944.

193. Miraki-Moud F, Ghazaly E, Ariza-McNaughton L, Hodby KA, Clear A, AnjosAfonso $F$, et al. Arginine deprivation using pegylated arginine deiminase has activity against primary acute myeloid leukemia cells in vivo. Blood. 2015;125(26):4060-8. https://doi.org/10.1182/blood-2014-10-608133.

194. Mussai F, Egan S, Higginbotham-Jones J, Perry T, Beggs A, Odintsova E, et al. Arginine dependence of acute myeloid leukemia blast proliferation: a novel therapeutic target. Blood. 2015;125(15):2386-96. https://doi.org/10.11 82/blood-2014-09-600643.
195. Willems L, Jacque N, Jacquel A, Neveux N, Maciel TT, Lambert M, et al. Inhibiting glutamine uptake represents an attractive new strategy for treating acute myeloid leukemia. Blood. 2013;122(20):3521-32. https://doi. org/10.1182/blood-2013-03-493163.

196. Ricciardi MR, Mirabilii S, Allegretti M, Licchetta R, Calarco A, Torrisi MR, et al. Targeting the leukemia cell metabolism by the CPT1a inhibition: functional preclinical effects in leukemias. Blood. 2015;126(16):1925-9. https://doi.org/1 0.1182/blood-2014-12-617498.

197. Lee EA, Angka L, Rota SG, Hanlon T, Mitchell A, Hurren R, et al. Targeting mitochondria with avocatin $B$ induces selective leukemia cell death. Cancer Res. 2015;75(12):2478-88. https://doi.org/10.1158/0008-5472.CAN-14-2676.

198. Jones CL, Stevens BM, D’Alessandro A, Culp-Hill R, Reisz JA, Pei S, et al. Cysteine depletion targets leukemia stem cells through inhibition of electron transport complex II. Blood. 2019;134(4):389-94. https://doi.org/1 $0.1182 /$ blood.2019898114

199. Wu D, Wang W, Chen W, Lian F, Lang L, Huang Y, et al. Pharmacological inhibition of dihydroorotate dehydrogenase induces apoptosis and differentiation in acute myeloid leukemia cells. Haematologica. 2018;103(9): 1472-83. https://doi.org/10.3324/haematol.2018.188185.

200. Cao L, Weetall M, Trotta C, Cintron K, Ma J, Kim MJ, et al. Targeting of hematologic malignancies with PTC299, A novel potent inhibitor of dihydroorotate dehydrogenase with favorable pharmaceutical properties. Mol Cancer Ther. 2019;18(1):3-16. https://doi.org/10.1158/1535-7163.MCT-1 8-0863.

201. Zhou J, Quah JY, Ng Y, Chooi JY, Toh SH, Lin B, et al. ASLAN003, a potent dihydroorotate dehydrogenase inhibitor for differentiation of acute myeloid leukemia. Haematologica. 2020;105(9):2286-97.

202. Christian S, Merz C, Evans L, Gradl S, Seidel H, Friberg A, et al. The novel dihydroorotate dehydrogenase (DHODH) inhibitor BAY 2402234 triggers differentiation and is effective in the treatment of myeloid malignancies. Leukemia. 2019;33(10):2403-15. https://doi.org/10.1038/s41375-019-0461-5.

203. Parmar S, Rundhaugen LM, Boehlke L, Riley M, Nabhan C, Raji A, et al. Phase II trial of arsenic trioxide in relapsed and refractory acute myeloid leukemia, secondary leukemia and/or newly diagnosed patients at least 65 years old. Leuk Res. 2004;28(9):909-19. https://doi.org/10.1016/j.leukres.2003.12.012.

204. Belzacq AS, El Hamel C, Vieira HL, Cohen I, Haouzi D, Métivier D, et al. Adenine nucleotide translocator mediates the mitochondrial membrane permeabilization induced by lonidamine, arsenite and CD437. Oncogene. 2001;20(52):7579-87. https://doi.org/10.1038/sj.onc.1204953.

205. Guo L, Shestov AA, Worth AJ, Nath K, Nelson DS, Leeper DB, et al. Inhibition of mitochondrial complex II by the anticancer agent lonidamine. J Biol Chem. 2016;291(1):42-57. https://doi.org/10.1074/jbc.M115.697516.

206. Guzman ML, Rossi RM, Karnischky L, Li X, Peterson DR, Howard DS, et al. The sesquiterpene lactone parthenolide induces apoptosis of human acute myelogenous leukemia stem and progenitor cells. Blood. 2005;105(11): 4163-9. https://doi.org/10.1182/blood-2004-10-4135.

207. Giri B, Gupta VK, Yaffe B, Modi S, Roy P, Sethi V, et al. Pre-clinical evaluation of Minnelide as a therapy for acute myeloid leukemia. J Transl Med. 2019; 17(1):163. https://doi.org/10.1186/s12967-019-1901-8.

208. Estrov Z, Shishodia S, Faderl S, Harris D, Van Q, Kantarjian HM, et al. Resveratrol blocks interleukin-1beta-induced activation of the nuclear transcription factor NF-kappaB, inhibits proliferation, causes S-phase arrest, and induces apoptosis of acute myeloid leukemia cells. Blood. 2003;102(3): 987-95. https://doi.org/10.1182/blood-2002-11-3550.

209. Figarola JL, Weng Y, Lincoln C, Horne D, Rahbar S. Novel dichlorophenyl urea compounds inhibit proliferation of human leukemia HL-60 cells by inducing cell cycle arrest, differentiation and apoptosis. Invest New Drugs. 2012;30(4):1413-25. https://doi.org/10.1007/s10637-011-9711-8.

210. Tardi P, Johnstone S, Harasym N, Xie S, Harasym T, Zisman N, et al. In vivo maintenance of synergistic cytarabine:daunorubicin ratios greatly enhances therapeutic efficacy. Leuk Res. 2009;33(1):129-39. https://doi.org/10.1016/j. leukres.2008.06.028.

211. Lancet JE, Uy GL, Cortes JE, Newell LF, Lin TL, Ritchie EK, et al. CPX-351 (cytarabine and daunorubicin) liposome for injection versus conventional cytarabine plus daunorubicin in older patients with newly diagnosed secondary acute myeloid leukemia. J Clin Oncol. 2018:36(26):2684-92. https://doi.org/10.1200/JCO.2017.77.6112.

212. Füller M, Klein M, Schmidt E, Rohde C, Göllner S, Schulze I, et al. 5azacytidine enhances efficacy of multiple chemotherapy drugs in AML and lung cancer with modulation of CpG methylation. Int J Oncol. 2015;46(3): 1192-204. https://doi.org/10.3892/ijo.2014.2792. 
213. Onec B, Okutan H, Albayrak M, Can ES, Aslan V, Koluman BU, et al. Combination therapy with azacitidine, etoposide, and cytarabine in the treatment of elderly acute myeloid leukemia patients: A single center experience. J Cancer Res Ther. 2018;14(5): 1105-11. https://doi.org/10.4103/0973-1482.187369.

214. Maiso P, Colado E, Ocio EM, Garayoa M, Martín J, Atadja P, et al. The synergy of panobinostat plus doxorubicin in acute myeloid leukemia suggests a role for HDAC inhibitors in the control of DNA repair. Leukemia. 2009;23(12):2265-74. https://doi.org/10.1038/leu.2009.182.

215. Garcia-Manero G, Tambaro FP, Bekele NB, Yang H, Ravandi F, Jabbour E, et al. Phase II trial of vorinostat with idarubicin and cytarabine for patients with newly diagnosed acute myelogenous leukemia or myelodysplastic syndrome. J Clin Oncol. 2012;30(18):2204-10. https://doi.org/10.1200/JCO.2 011.38.3265.

216. Ho AD, Lipp T, Ehninger G, Illiger HJ, Meyer P, Freund M, et al. Combination of mitoxantrone and etoposide in refractory acute myelogenous leukemia-an active and well-tolerated regimen. J Clin Oncol. 1988;6(2):213-7. https:// doi.org/10.1200/JCO.1988.6.2.213.

217. Im A, Amjad A, Agha M, Raptis A, Hou JZ, Farah R, et al. Mitoxantrone and etoposide for the treatment of acute myeloid leukemia patients in first relapse. Oncol Res. 2016;24(2):73-80. https://doi.org/10.3727/096504016X14 586627440156.

218. Janus A, Linke A, Cebula B, Robak T, Smolewski P. Rapamycin, the mTOR kinase inhibitor, sensitizes acute myeloid leukemia cells, $\mathrm{HL}-60$ cells, to the cytotoxic effect of arabinozide cytarabine. Anticancer Drugs. 2009;20(8):693701. https://doi.org/10.1097/CAD.0b013e32832e89b4.

219. Xu Q, Thompson JE, Carroll M. mTOR regulates cell survival after etoposide treatment in primary AML cells. Blood. 2005;106(13):4261-8. https://doi.org/1 0.1182/blood-2004-11-4468.

220. Perl AE, Kasner MT, Tsai DE, Vogl DT, Loren AW, Schuster SJ, et al. A phase I study of the mammalian target of rapamycin inhibitor sirolimus and MEC chemotherapy in relapsed and refractory acute myelogenous leukemia. Clin Cancer Res. 2009;15(21):6732-9. https://doi.org/10.1158/1078-0432.CCR-090842.

221. Burnett AK, Das Gupta E, Knapper S, Khwaja A, Sweeney M, Kjeldsen L, et al. Addition of the mammalian target of rapamycin inhibitor, everolimus, to consolidation therapy in acute myeloid leukemia: experience from the UK NCRI AML17 trial. Haematologica. 2018;103(10):1654-61. https://doi.org/1 0.3324/haematol.2018.189514.

222. Tiong IS, Tan P, McManus J, Cummings N, Sadawarte S, Catalano J, et al. Phase lb study of the mTOR inhibitor everolimus with low dose cytarabine in elderly acute myeloid leukemia. Leuk Lymphoma. 2018;59(2):493-6. https://doi.org/10.1080/10428194.2017.1334122.

223. Rushworth SA, Murray MY, Zaitseva L, Bowles KM, MacEwan DJ. Identification of Bruton's tyrosine kinase as a therapeutic target in acute myeloid leukemia. Blood. 2014;123(8):1229-38. https://doi.org/10.1182/ blood-2013-06-511154.

224. Cortes JE, Jonas BA, Graef T, Luan Y, Stein AS. Clinical experience with ibrutinib alone or in combination with either cytarabine or azacitidine in patients with acute myeloid leukemia. Clin Lymphoma Myeloma Leuk. 2019; 19(8):509-15.e1.

225. Nguyen LXT, Troadec E, Kalvala A, Kumar B, Hoang DH, Viola D, et al. The Bcl-2 inhibitor venetoclax inhibits Nrf2 antioxidant pathway activation induced by hypomethylating agents in AML. J Cell Physiol. 2019;234(8): 14040-9. https://doi.org/10.1002/jcp.28091.

226. Jones CL, Stevens BM, D'Alessandro A, Reisz JA, Culp-Hill R, Nemkov T, et al. Inhibition of amino acid metabolism selectively targets human leukemia stem cells. Cancer Cell. 2018;34(5):724-40.e4.

227. DiNardo CD, Pratz KW, Letai A, Jonas BA, Wei AH, Thirman M, et al. Safety and preliminary efficacy of venetoclax with decitabine or azacitidine in elderly patients with previously untreated acute myeloid leukaemia: a nonrandomised, open-label, phase 1b study. Lancet Oncol. 2018;19(2):216-28. https://doi.org/10.1016/S1470-2045(18)30010-X.

228. Niu X, Zhao J, Ma J, Xie C, Edwards H, Wang G, et al. Binding of released Bim to Mcl-1 is a mechanism of intrinsic resistance to ABT-199 which can be Overcome by combination with daunorubicin or cytarabine in AML cells. Clin Cancer Res. 2016;22(17):4440-51. https://doi.org/10.1158/1078-0432.CCR-15-3057.

229. Wei AH, Strickland SA, Hou JZ, Fiedler W, Lin TL, Walter RB, et al. Venetoclax Combined With Low-Dose Cytarabine for Previously Untreated Patients With Acute Myeloid Leukemia: Results From a Phase Ib/II Study. J Clin Oncol. 2019;37(15):1277-84. https://doi.org/10.1200/JCO.18.01600.
230. Karol SE, Alexander TB, Budhraja A, Pounds SB, Canavera K, Wang L, et al. Venetoclax in combination with cytarabine with or without idarubicin in children with relapsed or refractory acute myeloid leukaemia: a phase 1 , dose-escalation study. Lancet Oncol. 2020;21(4):551-60. https://doi.org/10.1 016/S1470-2045(20)30060-7.

231. Chyla B, Daver N, Doyle K, McKeegan E, Huang X, Ruvolo V, et al. Genetic biomarkers of sensitivity and resistance to venetoclax monotherapy in patients with relapsed acute myeloid leukemia. Am J Hematol. 2018;93(8): E202-5. https://doi.org/10.1002/ajh.25146.

232. Cathelin S, Sharon D, Subedi A, Cojocari D, Phillips DC, Leverson JD, et al. Combination of Enasidenib and venetoclax shows superior anti-leukemic activity against IDH2 mutated AML in patient-derived xenograft models. Blood. 2018;132(Suppl. 1):562. https://doi.org/10.1182/blood-2018-99-119688.

233. Moujalled DM, Pomilio G, Ghiurau C, Ivey A, Salmon J, Rijal S, et al. Combining BH3-mimetics to target both BCL-2 and MCL1 has potent activity in pre-clinical models of acute myeloid leukemia. Leukemia. 2019; 33(4):905-17. https://doi.org/10.1038/s41375-018-0261-3.

234. Anstee NS, Bilardi RA, Ng AP, Xu Z, Robati M, Vandenberg CJ, et al. Impact of elevated anti-apoptotic MCL-1 and BCL-2 on the development and treatment of MLL-AF9 AML in mice. Cell Death Differ. 2019;26(7):1316-31. https://doi.org/10.1038/s41418-018-0209-1.

235. Cerella C, Gaigneaux A, Mazumder A, Lee JY, Saland E, Radogna F, et al. BCl2 protein family expression pattern determines synergistic pro-apoptotic effects of BH3 mimetics with hemisynthetic cardiac glycoside UNBS1450 in acute myeloid leukemia. Leukemia. 2017;31(3):755-9. https://doi.org/10.103 8/leu.2016.341.

236. Wei $Y$, Kadia T, Tong $W$, Zhang M, Jia Y, Yang $H$, et al. The combination of a histone deacetylase inhibitor with the $\mathrm{BCl}-2$ homology domain-3 mimetic GX15-070 has synergistic antileukemia activity by activating both apoptosis and autophagy. Clin Cancer Res. 2010;16(15):3923-32. https://doi.org/10.11 58/1078-0432.CCR-10-0032.

237. Cai T, Lorenzi PL, Rakheja D, Pontikos MA, Lodi A, Han L, et al. Gls Inhibitor CB-839 Modulates Cellular Metabolism in AML and Potently Suppresses AML Cell Growth When Combined with 5-Azacitidine. Blood. 2016;128(22): 4064. https://doi.org/10.1182/blood.V128.22.4064.4064.

238. Gregory MA, Nemkov T, Reisz JA, Zaberezhnyy V, Hansen KC, D'Alessandro A, et al. Glutaminase inhibition improves FLT3 inhibitor therapy for acute myeloid leukemia. Exp Hematol. 2018:58:52-8. https://doi.org/10.1016/j. exphem.2017.09.007.

239. Capizzi RL, Davis R, Powell B, Cuttner J, Ellison RR, Cooper MR, et al. Synergy between high-dose cytarabine and asparaginase in the treatment of adults with refractory and relapsed acute myelogenous leukemia--a Cancer and Leukemia Group B Study. J Clin Oncol. 1988;6(3):499-508. https://doi.org/1 0.1200/JCO.1988.6.3.499.

240. Ahmed T, Holwerda S, Klepin HD, Isom S, Ellis LR, Lyerly S, et al. High dose cytarabine, mitoxantrone and l-asparaginase (HAMA) salvage for relapsed or refractory acute myeloid leukemia (AML) in the elderly. Leuk Res. 2015;39(9): 945-9. https://doi.org/10.1016/j.leukres.2015.05.010.

241. Estañ MC, Calviño E, Calvo S, Guillén-Guío B, MeC B-A, de Blas E, et al. Apoptotic efficacy of etomoxir in human acute myeloid leukemia cells. Cooperation with arsenic trioxide and glycolytic inhibitors, and regulation by oxidative stress and protein kinase activities. Plos One. 2014;9(12): e115250.

242. Tabe Y, Saitoh K, Yang H, Sekihara K, Yamatani K, Ruvolo V, et al. Inhibition of FAO in AML co-cultured with BM adipocytes: mechanisms of survival and chemosensitization to cytarabine. Sci Rep. 2018;8(1):16837. https://doi.org/1 0.1038/s41598-018-35198-6.

243. Wang F, Liu Z, Zeng J, Zhu H, Li J, Cheng X, et al. Metformin synergistically sensitizes FLT3-ITD-positive acute myeloid leukemia to sorafenib by promoting mTOR-mediated apoptosis and autophagy. Leuk Res. 2015; 39(12):1421-7. https://doi.org/10.1016/j.leukres.2015.09.016.

244. Sabnis HS, Bradley HL, Tripathi S, Yu WM, Tse W, Qu CK, et al. Synergistic cell death in FLT3-ITD positive acute myeloid leukemia by combined treatment with metformin and 6-benzylthioinosine. Leuk Res. 2016;50:132-40. https:// doi.org/10.1016/j.leukres.2016.10.004.

245. Yuan F, Cheng C, Xiao F, Liu H, Cao S, Zhou G. Inhibition of mTORC1/ P70S6K pathway by Metformin synergistically sensitizes Acute Myeloid Leukemia to Ara-C. Life Sci. 2020;243:117276. https://doi.org/10.1016/j.lfs.202 0.117276 .

246. Han L, Cavazos A, Baran N, Zhang Q, Kuruvilla VM, Gay JP, et al. Mitochondrial OxPhos as survival mechanism of minimal residual AML cells 
after induction chemotherapy: survival benefit by complex I inhibition with IACS-010759. Blood. 2019;134(Suppl. 1):5161. https://doi.org/10.1182/blood-2 019-124475

247. Pfefferle A, Mailloux RJ, Adjeitey CN, Harper ME. Glutathionylation of UCP2 sensitizes drug resistant leukemia cells to chemotherapeutics. Biochim Biophys Acta. 2013;1833(1):80-9. https://doi.org/10.1016/j.bbamcr.2012.10. 006.

248. Douer D, Watkins K, Louie R, Weitz I, Mohrbacher A, Levine AM. Treatment of acute myelogenous leukemia (non-APL) with intravenous Trisenox (arsenic trioxide) and ascorbic acid: preliminary results. Blood. 2004;104(11): 1815. https://doi.org/10.1182/blood.V104.11.1815.1815.

249. Chau D, Ng K, Chan TS, Cheng YY, Fong B, Tam S, et al. Azacytidine sensitizes acute myeloid leukemia cells to arsenic trioxide by up-regulating the arsenic transporter aquaglyceroporin 9. J Hematol Oncol. 2015;8(1):46. https://doi.org/10.1186/s13045-015-0143-3.

250. Welch JS, Klco JM, Gao F, Procknow E, Uy GL, Stockerl-Goldstein KE, et al. Combination decitabine, arsenic trioxide, and ascorbic acid for the treatment of myelodysplastic syndrome and acute myeloid leukemia: a phase I study. Am J Hematol. 2011;86(9):796-800. https://doi.org/10.1002/a jh.22092.

251. Roboz GJ, Ritchie EK, Curcio T, Provenzano J, Carlin R, Samuel M, et al. Arsenic trioxide and low-dose cytarabine in older patients with untreated acute myeloid leukemia, excluding acute promyelocytic leukemia. Cancer. 2008;113(9):2504-11. https://doi.org/10.1002/cncr.23855.

252. Burnett AK, Hills RK, Hunter A, Milligan D, Kell J, Wheatley K, et al. The addition of arsenic trioxide to low-dose Ara-C in older patients with AML does not improve outcome. Leukemia. 2011;25(7):1122-7. https://doi.org/1 0.1038/leu.2011.59

253. Wetzler M, Andrews C, Ford LA, Tighe S, Barcos M, Sait SN, et al. Phase 1 study of arsenic trioxide, high-dose cytarabine, and idarubicin to downregulate constitutive signal transducer and activator of transcription 3 activity in patients aged $<60$ years with acute myeloid leukemia. Cancer 2011;117(21):4861-8. https://doi.org/10.1002/cncr.26097.

254. Dembitz V, Lalic H, Ostojic A, Vrhovac R, Banfic H, Visnjic D. The mechanism of synergistic effects of arsenic trioxide and rapamycin in acute myeloid leukemia cell lines lacking typical t(15;17) translocation. Int J Hematol. 2015; 102(1):12-24. https://doi.org/10.1007/s12185-015-1776-2.

255. Liesveld JL, Rosell KE, Bechelli J, Lu C, Messina P, Mulford D, et al. Proteasome inhibition in myelodysplastic syndromes and acute myelogenous leukemia cell lines. Cancer Invest. 2011;29(7):439-50. https:// doi.org/10.3109/07357907.2011.590567.

256. Ganesan S, Alex AA, Chendamarai E, Balasundaram N, Palani HK, David S, et al. Rationale and efficacy of proteasome inhibitor combined with arsenic trioxide in the treatment of acute promyelocytic leukemia. Leukemia. 2016; 30(11):2169-78. https://doi.org/10.1038/leu.2016.227.

257. Kulkarni U, Ganesan S, Alex AA, Palani H, David S, Balasundaram N, et al. A phase II study evaluating the role of bortezomib in the management of relapsed acute promyelocytic leukemia treated upfront with arsenic trioxide. Cancer Med. 2020;9(8):2603-10. https://doi.org/10.1002/cam4.2883.

258. Calviño E, Estañ MC, Simón GP, Sancho P, MeC B-A, de Blas E, et al. Increased apoptotic efficacy of lonidamine plus arsenic trioxide combination in human leukemia cells. Reactive oxygen species generation and defensive protein kinase (MEK/ERK, Akt/mTOR) modulation. Biochem Pharmacol. 2011;82(11):1619-29. https://doi.org/10.1016/j.bcp.2011.08.017.

259. Emadi A, Sadowska M, Carter-Cooper B, Bhatnagar V, van der Merwe I, Levis $\mathrm{MJ}$, et al. Perturbation of cellular oxidative state induced by dichloroacetate and arsenic trioxide for treatment of acute myeloid leukemia. Leuk Res. 2015;39(7):719-29. https://doi.org/10.1016/j.leukres.2015.04.002.

260. Zheng PZ, Wang KK, Zhang QY, Huang QH, Du YZ, Zhang QH, et al. Systems analysis of transcriptome and proteome in retinoic acid/arsenic trioxide-induced cell differentiation/apoptosis of promyelocytic leukemia. Proc Natl Acad Sci U S A. 2005;102(21):7653-8. https://doi.org/10.1073/pnas. 0502825102

261. Lo-Coco F, Avvisati G, Vignetti M, Thiede C, Orlando SM, lacobelli S, et al. Retinoic acid and arsenic trioxide for acute promyelocytic leukemia. N Engl J Med. 2013;369(2):111-21. https://doi.org/10.1056/NEJMoa1300874.

262. Rotin LE, Gronda M, Maclean N, Lin F-H, Wrana J, Datti A, et al. Ibrutinib sensitizes AML cells to ROS inducers via a BTK-independent mechanism. Blood. 2014;124(21):2226. https://doi.org/10.1182/blood.V124.21.2226.2226.

263. Liu Y, Chen F, Wang S, Guo X, Shi P, Wang W, et al. Low-dose triptolide in combination with idarubicin induces apoptosis in AML leukemic stem-like
KG1a cell line by modulation of the intrinsic and extrinsic factors. Cell Death Dis. 2013;4(12):e948. https://doi.org/10.1038/cddis.2013.467.

264. Yaseen A, Chen S, Hock S, Rosato R, Dent P, Dai Y, et al. Resveratrol sensitizes acute myelogenous leukemia cells to histone deacetylase inhibitors through reactive oxygen species-mediated activation of the extrinsic apoptotic pathway. Mol Pharmacol. 2012;82(6):1030-41. https://doi. org/10.1124/mol.112.079624.

265. Walter RB, Pirga JL, Cronk MR, Mayer S, Appelbaum FR, Banker DE. PK11195, a peripheral benzodiazepine receptor (pBR) ligand, broadly blocks drug efflux to chemosensitize leukemia and myeloma cells by a pBRindependent, direct transporter-modulating mechanism. Blood. 2005; 106(10):3584-93. https://doi.org/10.1182/blood-2005-02-0711.

266. Bosnjak M, Ristic B, Arsikin K, Mircic A, Suzin-Zivkovic V, Perovic V, et al. Inhibition of mTOR-dependent autophagy sensitizes leukemic cells to cytarabine-induced apoptotic death. PLoS One. 2014;9(4):e94374. https://doi. org/10.1371/journal.pone.0094374.

267. Kim Y, Eom Jl, Jeung HK, Jang JE, Kim JS, Cheong JW, et al. Induction of cytosine arabinoside-resistant human myeloid leukemia cell death through autophagy regulation by hydroxychloroquine. Biomed Pharmacother. 2015; 73:87-96. https://doi.org/10.1016/j.biopha.2015.05.012.

268. Cheong JW, Kim Y, Eom Jl, Jeung HK, Min YH. Enhanced autophagy in cytarabine arabinoside-resistant U937 leukemia cells and its potential as a target for overcoming resistance. Mol Med Rep. 2016;13(4):3433-40. https:// doi.org/10.3892/mmr.2016.4949.

269. Tanios R, Bekdash A, Kassab E, Stone E, Georgiou G, Frankel AE, et al. Human recombinant arginase I(Co)-PEG5000 [HuArgI(Co)-PEG5000]-induced arginine depletion is selectively cytotoxic to human acute myeloid leukemia cells. Leuk Res. 2013;37(11):1565-71. https://doi.org/10.1016/j.leukres.2013.08. 007.

270. Torgersen ML, Engedal N, Bøe SO, Hokland P, Simonsen A. Targeting autophagy potentiates the apoptotic effect of histone deacetylase inhibitors in t(8;21) AML cells. Blood. 2013;122(14):2467-76. https://doi.org/10.1182/ blood-2013-05-500629.

271. Nawrocki ST, Han Y, Visconte V, Przychodzen B, Espitia CM, Phillips J, et al. The novel autophagy inhibitor ROC-325 augments the antileukemic activity of azacitidine. Leukemia. 2019;33(12):2971-4. https://doi.org/10.1038/s41375019-0529-2.

272. Bhattacharya S, Piya S, McQueen T, Konopleva M, Andreeff M, Borthakur G. Inhibition of Unc-1 like autophagy activating kinase 1 (ULK1) is highly synergistic with chemotherapy and Bcl2 inhibition in acute myeloid leukemia (AML). Blood. 2017;130(Suppl. 1):1248.

273. Bhattacharya S, Piya S, Zhang Q, Baran N, McQueen T, Davis RE, et al. Targeting autophagy kinase ULK1 can reverse BCI2 inhibitor (ABT-199) induced autophagy to overcome acquired resistance in acute myeloid leukemia. Blood. 2018;132(Suppl. 1):3934. https://doi.org/10.1182/blood-201 8-99-114817.

274. Qiu L, Zhou G, Cao S. Targeted inhibition of ULK1 enhances daunorubicin sensitivity in acute myeloid leukemia. Life Sci. 2020;243:117234. https://doi. org/10.1016/.j.lfs.2019.117234.

275. Stewart HJS, Chaudry S, Crichlow A, Luiling Feilding F, Chevassut TJT. BET Inhibition suppresses S100A8 and S100A9 expression in acute myeloid leukemia cells and synergises with daunorubicin in causing cell death. Bone Marrow Res. 2018:2018:5742954.

276. Herrmann H, Blatt K, Shi J, Gleixner KV, Cerny-Reiterer S, Müllauer L, et al. Small-molecule inhibition of BRD4 as a new potent approach to eliminate leukemic stem- and progenitor cells in acute myeloid leukemia AML. Oncotarget. 2012;3(12):1588-99. https://doi.org/10.18632/oncotarget.733.

277. Karjalainen R, Liu M, Kumar A, Parsons A, He L, Malani DR, et al. Combined targeting of BET family proteins and BCL2 Is synergistic in acute myeloid leukemia cells overexpressing S100A8 and S100A9. Blood. 2018;132(Suppl. 1): 2634. https://doi.org/10.1182/blood-2018-99-118890.

278. Ouchida AT, Li Y, Geng J, Najafov A, Ofengeim D, Sun X, et al. Synergistic effect of a novel autophagy inhibitor and quizartinib enhances cancer cell death. Cell Death Dis. 2018;9(2):138. https://doi.org/10.1038/s41419-017-01 70-9.

279. Ha YN, Song S, Orlikova-Boyer B, Cerella C, Christov C, Kijjoa A, et al. Petromurin C induces protective autophagy and apoptosis in FLT3-ITDpositive AML: synergy with gilteritinib. Mar Drugs. 2020;18(1):57.

280. Bai H, Cao Z, Deng C, Zhou L, Wang C. miR-181a sensitizes resistant leukaemia HL-60/Ara-C cells to Ara-C by inducing apoptosis. J Cancer Res Clin Oncol. 2012;138(4):595-602. https://doi.org/10.1007/s00432-011-1137-3. 
281. Huang X, Schwind S, Santhanam R, Eisfeld AK, Chiang CL, Lankenau M, et al. Targeting the RAS/MAPK pathway with miR-181a in acute myeloid leukemia. Oncotarget. 2016;7(37):59273-86. https://doi.org/10.18632/oncota rget.11150.

282. Lu F, Zhang J, Ji M, Li P, Du Y, Wang H, et al. miR-181b increases drug sensitivity in acute myeloid leukemia via targeting HMGB1 and Mcl-1. Int J Oncol. 2014;45(1):383-92. https://doi.org/10.3892/ijo.2014.2390.

283. Gao SM, Chen C, Wu J, Tan Y, Yu K, Xing CY, et al. Synergistic apoptosis induction in leukemic cells by miR-15a/16-1 and arsenic trioxide. Biochem Biophys Res Commun. 2010;403(2):203-8. https://doi.org/10.1016/j.bbrc.201 0.10.137.

284. Liu Y, Lei P, Qiao H, Sun K, Lu X, Bao F, et al. miR-9 Enhances the chemosensitivity of AML cells to daunorubicin by targeting the EIF5A2/ MCL-1 axis. Int J Biol Sci. 2019;15(3):579-86. https://doi.org/10.7150/ijbs.2 9775.

285. Garzon R, Pichiorri F, Marcucci G, Kornblau S, Andreeff M, Croce C. MiRNA29b targets MCL-1 and is down-regulated in chemotherapy-resistant acute myeloid leukemia (AML). Blood. 2007;110(11):717. https://doi.org/10.1182/ blood.V110.11.717.717.

286. Huang X, Schwind S, Yu B, Santhanam R, Wang H, Hoellerbauer P, et al. Targeted delivery of microRNA-29b by transferrin-conjugated anionic lipopolyplex nanoparticles: a novel therapeutic strategy in acute myeloid leukemia. Clin Cancer Res. 2013;19(9):2355-67. https://doi.org/10.1158/10780432.CCR-12-3191.

287. Gocek E, Wang X, Liu X, Liu CG, Studzinski GP. MicroRNA-32 upregulation by 1,25-dihydroxyvitamin D3 in human myeloid leukemia cells leads to Bim targeting and inhibition of AraC-induced apoptosis. Cancer Res. 2011;71(19): 6230-9. https://doi.org/10.1158/0008-5472.CAN-11-1717.

288. Kurtz SE, Eide CA, Kaempf A, Khanna V, Savage SL, Rofelty A, et al. Molecularly targeted drug combinations demonstrate selective effectiveness for myeloid- and lymphoid-derived hematologic malignancies. Proc Nat Acad Sci U S A. 2017;114(36):E7554-E63. https://doi.org/10.1073/pnas.1703 094114.

289. Chang E, Ganguly S, Rajkhowa T, Gocke CD, Levis M, Konig H. The combination of FLT3 and DNA methyltransferase inhibition is synergistically cytotoxic to FLT3/ITD acute myeloid leukemia cells. Leukemia. 2016;30(5): 1025-32. https://doi.org/10.1038/leu.2015.346.

290. Ramaswamy S. Rational design of cancer-drug combinations. N Engl J Med. 2007;357(3):299-300. https://doi.org/10.1056/NEJMcibr072593.

291. Si W, Shen J, Zheng H, Fan W. The role and mechanisms of action of microRNAs in cancer drug resistance. Clin Epigenetics. 2019;11(1):25. https:// doi.org/10.1186/s13148-018-0587-8.

292. Auberger P, Puissant A. Autophagy, a key mechanism of oncogenesis and resistance in leukemia. Blood. 2017;129(5):547-52. https://doi.org/10.1182/ blood-2016-07-692707.

\section{Publisher's Note}

Springer Nature remains neutral with regard to jurisdictional claims in published maps and institutional affiliations.

Ready to submit your research? Choose BMC and benefit from:

- fast, convenient online submission

- thorough peer review by experienced researchers in your field

- rapid publication on acceptance

- support for research data, including large and complex data types

- gold Open Access which fosters wider collaboration and increased citations

- maximum visibility for your research: over $100 \mathrm{M}$ website views per year

At BMC, research is always in progress.

Learn more biomedcentral.com/submissions 